$$
2 / 88^{3} \text { wh (1) I-20494 DR-0957-1 }
$$

\title{
Reaction of the Topopah Spring Tuff With J-13 Water at $120^{\circ} \mathrm{C}$ \\ V. M. Oversby
}

\section{MASIER}

July 18, 1984

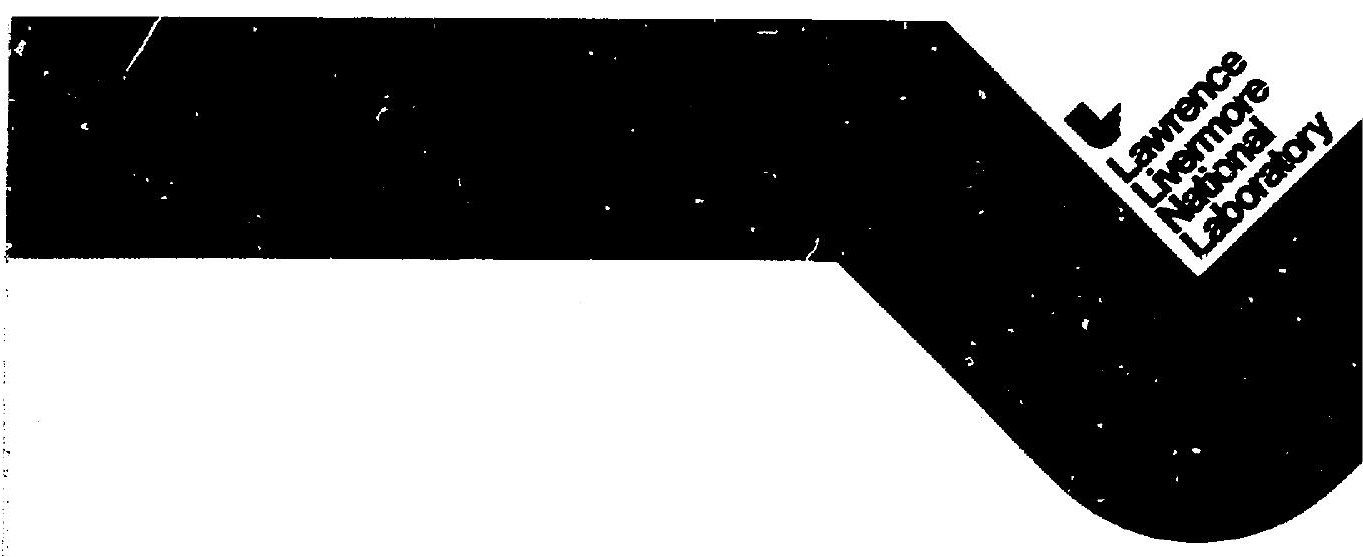




\title{
Reaction of the Topopah Spring Tuff With J-13 Water at $120^{\circ} \mathrm{C}$
}

\author{
V. M. Oversby
}

Manuscript date: July 18, 1984

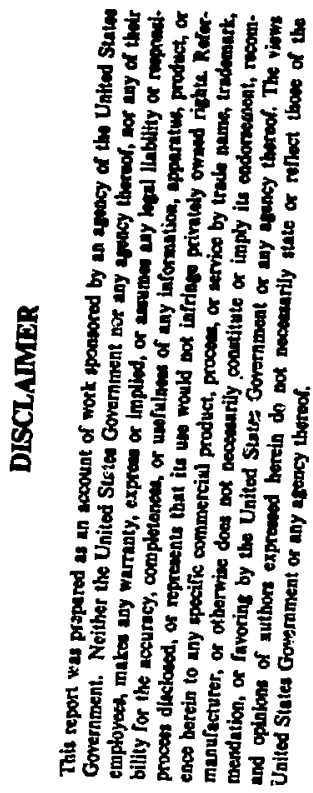

\section{LA WRENCE LIVERMORE LABORATORY University of California • Livermore, California • 94550}




\section{Contents}

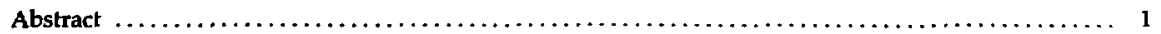

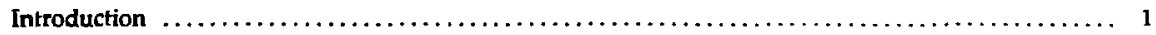

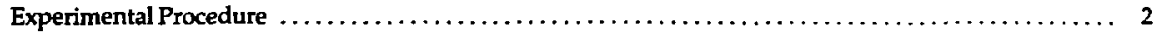

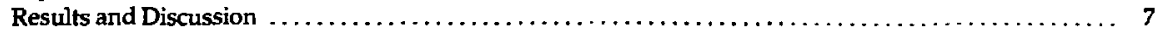

Composition of the Caliche Component $\ldots \ldots \ldots \ldots \ldots \ldots \ldots \ldots \ldots \ldots \ldots \ldots \ldots \ldots \ldots \ldots \ldots$

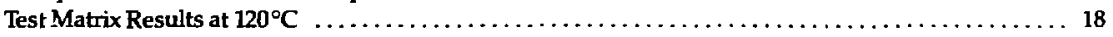

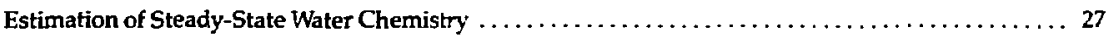

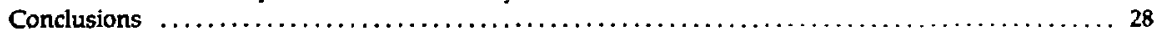

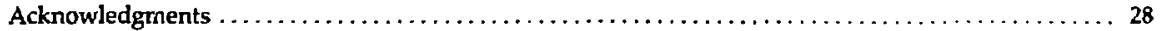

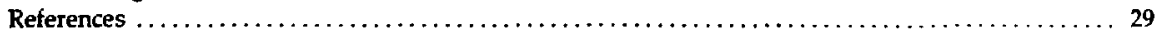

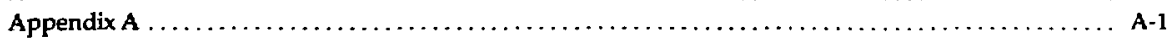




\title{
Reaction of the Topopah Spring Tuff With $\mathrm{J}-13$ Water at $120^{\circ} \mathrm{C}$
}

\begin{abstract}
The Nevada Nuclear Waste Storage Investigations (NNWSI) Project is examining the suitability of the Topopah Spring Member of the Paintbrush Tuff for potential development as a high level nuclear waste repository. As part of the NNWSI Project, the Lawrence Livermore National Laboratory (LLNL) is responsible for the design and testing of waste packages suitable for use in the Topopah Spring tuff at Yucca Mountain. Definition of the physical and chemical environment of the waste package is part of that task. This report describes a series of hydrothermal experiments using crushed tuff from the Topopah Spring Member and natural ground water from well J-13. The purpose of these experiments is to define the changes in water chemistry that would result from temperature changes caused by emplacing high level nuclear waste in a repository in the Topopah Spring tuff.

Experiments were conducted at $120^{\circ} \mathrm{C}$ in Teflon-lined reaction vessels at four separate rock-to-water ratios and for reaction times up to 72 days. The composition of evaporite deposits contained in the pores of the surface-outcrop rock material used in these experiments is determined from solution compositions resulting from treatment of the rock before the start of the experiments. Results from the experiments at $120^{\circ} \mathrm{C}$ are compared with previous experimental results from hydrothermal reaction of the Topopah Spring tuff with J-13 water at 90 and $150^{\circ} \mathrm{C}$.

The main conclusion that can be drawn from this work is that changes in the water chemistry due to heating of the rock-water system can be expected to be very minor. There is no significant source of anions $\left(\mathrm{F}^{-}, \mathrm{Cl}^{-}, \mathrm{NO}_{3}^{-}\right.$, or $\left.\mathrm{SO}_{4}^{-}\right)$in the rock; solution anion compositions after reaction of pretreated rock with $\mathrm{J}-\mathbf{1 3}$ water differ very little from the starting compositions. The major changes in cations are an increase in silica to approximately the level of cristobalite solubility, supersaturation of aluminum followed by slow precipitation, and fairly rapid precipitation of calcium and magnesium due to the retrograde solubility of calcite. These results are in good agreement with those previously reported for reaction of the tuff with J-13 water at 90 and $150^{\circ} \mathrm{C}$.
\end{abstract}

\section{Introduction}

Lawrence Livermore National Laboratory is developing designs for high level nuclear waste packages as part of the NNWSI Project. The potential repository site under study is located at Yucca Mountain in Nye County, Nevada; the reference repository horizon is in the Topopah Spring Member of the Paintbrush Tuff. At the proposed repository level the tuff is densely welded and devitrified. The rock consists predominantly of a fine-grained intergrown assemblage of quartz, cristobalite, and alkali feldspar, with a small proportion of phenoctysts. Phenocryst min-

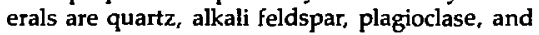
biotite.

Performance objectives for high-level nuclear waste packages, as given in the Nuclear Regula- tory Commission's regulations (10 CFR Part 60), require prediction of the corrosion performance of metals for up to $\mathbf{1 0 0 0}$ years, and of the performance of waste forms for up to 10,000 years. Successful prediction of performance for these long time periods requires a thorough understanding of the physical and chemical environmental conditions to which the packages will be subjected. Definition of the waste package environment involves detailed description of the pre-emplacement (ambient) conditions at the proposed repository horizon and deiermination of the changes that will result after erculacement of waste packages.

Construction of a high-level waste repository can produce three types of changes in the repository and surrounding environment. First, mining 
causes physical changes in the rock unit. Second, the radiation field produced by the waste can cause potential environmental changes. Third, the thermal output of the waste will heat the surroundings, causing physical and chemical changes in the repository rock and water systems. This report addresses the chemical changes caused by heating of repository rock with representative ground water.

The experiments were conducted using Topopah Spring tuff (Tpt) collected from Fran Ridge, several miles east of Yucca Mountain, and water from ivell $\mathrm{J}-13$. The locations of the potential repository site at Yucca Mountain, Fran Ridge, and J-13 are shown in Fig. 1. The elevation is lower at J-13 than at Yucca Mountain, and the Tpt lies below the water table. The Tpt is the major producing horizon for J-13; thus, the water chemistry is probably close to the prevailing chemistry in the Tpt at Yucca Mountain. At Yucca Mountain, the Tpt lies well above the water table in the unsaturated zone. We have not yet obtained water samples from this region, but collection of samples is planned as part of the exploratory shaft testing program. Until samples of water are available from the unsaturated repository horizon, the water from well J-13 has been adopted as a reference water chemistry for NNWSI experimental work.

The expected environmental conditions in the unsaturated zone limit the temperature at which liquid water will exist. For the expected case with no substantial sealing of fractures and pores in the host rock, the local atmospheric boiling point of unconfined water is approximately $95^{\circ} \mathrm{C}$. Water contained in pores is held by capillary forces; this water might have a somewhat higher effective boiling point. To bracket the expected temperature range, and to provide data for geochemical modeling studies, hydrothermal experiments are being conducted over a range of temperatures. The experiments described in this report wereconducted at $120^{\circ} \mathrm{C}$. Results from experiments conducted at 90 and $150^{\circ} \mathrm{C}$ have already been reported (Oversby, 1984).

The experiments described here used crushed rock and Teflon-lined reaction vessels. The techniques used required quenching of solutions before separating the rock and water after reaction. Other experiments are in progress that use goldbag rocking autoclaves, which allow sampling at temperature. Some experiments also in progress or recently completed use cere wafer Tpt tuff, both from outcrop samples and from drill cores. The core wafer experiments allow jdentification of alteration products formed in the rock as well as identification of secondary phases formed by precipitation from solution. Results from these experiments will be the subject of separate reports.

\section{Experimental Procedure}

The water used in these experiments was obtained from well J-13 at the Nevada Test Site (shown in Fig. 1). Water sampling and storage procedures are described in Oversby (1984).

The rock samples were collected from an outcrop located at Fran Ridge (Fig. 1). A detailed description of the locality is given by Knauss (1984). Procedures used to prepare the rock for experiments are described by Oversby (1984). The rock material was less than 60 mesh size ( 250 micron) and was from split number A-3.

All experiments were conducted in Teflon capsules encased in metal containers. Standard Parr Arid Digestion Bombs (model number 4748) were used. They were cleaned at $120^{\circ} \mathrm{C}$ before use by the procedure given in Oversby (1984).

The material obtained from surface outcrops near Yucca Mountain contains readily soluble material that is not present in rocks protected by a significant amount of overlying rock (Oversby, 1983).
The soluble material can be easily removed by shaking the rock powder in water for two minutes, allowing the powder to settle, and decanting the solution. A further step of cooking overnight with J-13 water ensures substantially complete removal of the soluble material. The rock samples were pretreated using the room-temperature shaking step and an overnight cook in J-13 water at $120^{\circ} \mathrm{C}$. The chemical compositions of these rinse solutions, which are discussed in the following section of this report, can be used to determine the composition of the soluble component. A detailed description of the pretreatment procedure is given in Oversby (1984).

At the start of the experiments J- 13 water was weighed into the Teflon capsules containing pretreated rock. The amount of water used was kept constant at $48 \mathrm{~g}$ for all experiments; rock weights of $0.4,0.8,1.6$, and $3.2 \mathrm{~g}$ were used. After water was added to the capsule, it was closed, placed in 


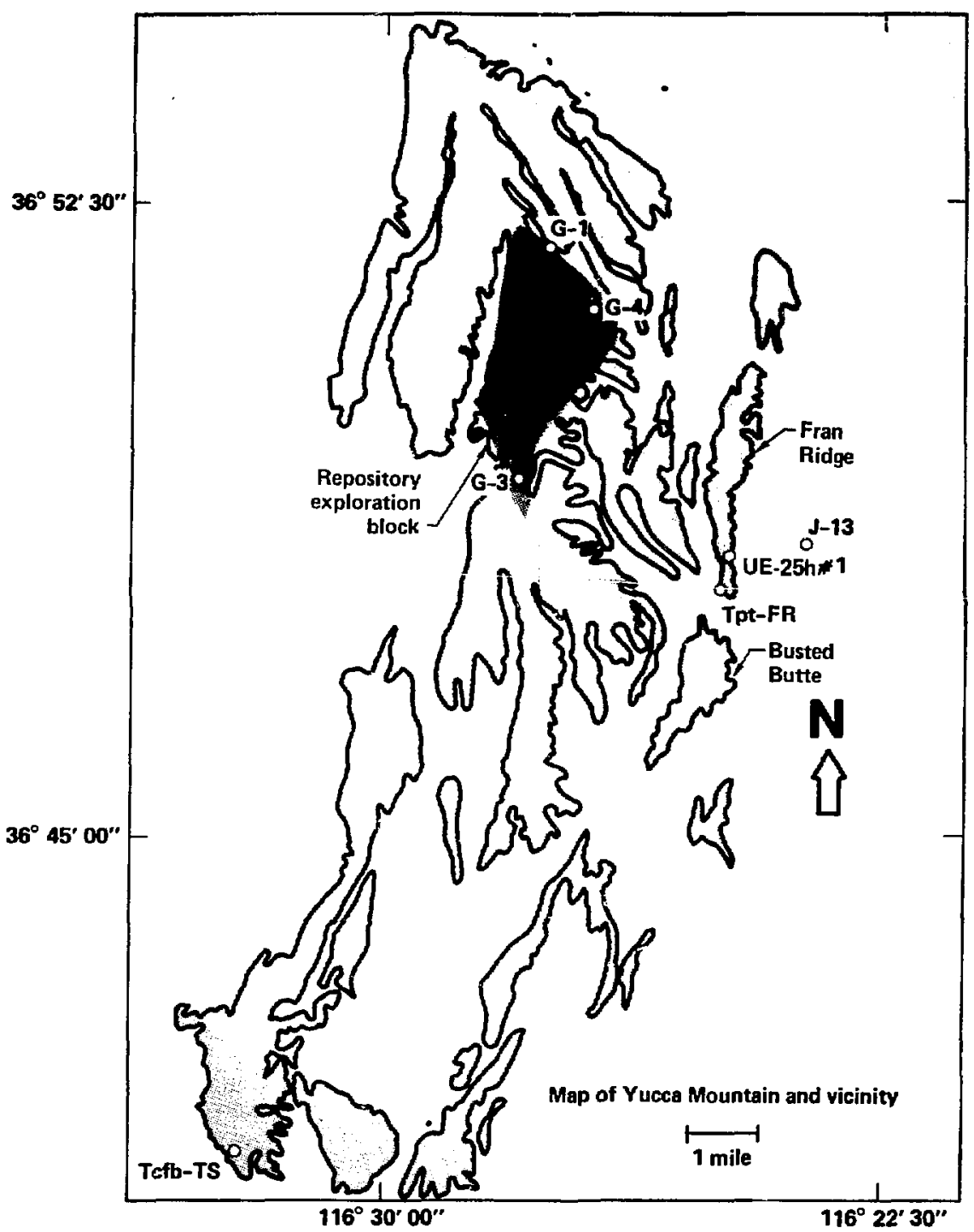

Figure 1. Map showing the location of Yucca Mountain, Fran Ridge, and well J-13. The outcrop locality for rock samples used in this work is marked Tpt-FR. Tcfb-TS is the outcrop locality for Bullfrog tuff samples. Other localities marked are drill holes. 
the outer metal container, and the assembly was placed in a Blue $M$ oven that had been preheated to $120^{\circ} \mathrm{C}$. The assembly remained in the oven for a reaction time of $1,3,6,12,24,36,48,60$, or 72 days.

At the end of the predetermined reaction time the assembly was removed from the oven, opened as soon as it was cool enough to handle (approximately $50^{\circ} \mathrm{C}$ ), and the contents were allowed to cool to room temperature. The $\mathrm{pH}$ of the liquid was measured with a meter that had been calibrated using standard solutions of $\mathrm{pH} 7$ and 10 . Following $\mathrm{pH}$ measurement, the solution was filtered through $\# 40$ filter paper and then through a 0.7 -micron filter. The filtered solution was split into four portions: (1) for anion analysis, stored in plastic, (2) for alkalinity, stored in glass, (3) and (4) acidified with two drops of $50 \% \mathrm{HNO}_{3}$ per $6 \mathrm{ml}$ of sample, and stored in plastic for later analysis by inductively coupled plasma (ICP) spectrometry. The rock sample was recovered on the filter paper, dried in air, and transferred to a small storage bottle when dry.

Cation analyses were performed using an automated $\mathrm{ICP}$ spectrometer system. The system, detailed in Peck et al. (1979), uses a polychrometer operated in the fixed-channel mode, giving simultaneous analysis for $\mathbf{2 8}$ elements. It is calibrated with standard solutions, and the operator employs a "check standard" that is run as a regular sample during each series of analyses. During th: course of these experiments some difficulties wt : encountered with results for boron and potassium. These difficulties were identified through the use of control blank samples of J-13 water that are regularly submitted along with the hydrotherinal test solutions. The control blanks of J-13 are given identification numbers that make them appear to the ICP operator to be part of the hydrothermal test set.

Table 1 gives a summary of results on $\mathrm{J}-13$ control blank samples and one set of six J-13 analyses run by the ICP operator to confirm that the boron and potassium analysis problems had been corrected. These samples (Table 1 b) were know'n by the operator to be J-13. The boron problem occurred in analyses performed on $8 / 4 / 83$, and in all analyses during the period from December 1983 through March 1984. The boron content for control blanks run during this period was reported as below detection limits. The problem was subsequently identified as having been caused by incorrect data storage and reduction in the computer control system. This resulted in reported concentrations for boron that were systematically low by about $0.1 \mathrm{ppm}$. Since this is approximately the bo- ron concentration in J-13, results for control blanks were reported as near or below the detection limit (i.e., close to zero).

The boron problem was corrected in May 1984, as can be seen in Table 1a. These analyses revealed a problem with potassium that had not previously been encountered. The potassium concentration of $\mathrm{J}-13$ is about 5 ppm; the analyses of control blanks run on 5/17/84 gave approximately $3 \mathrm{ppm}$. In addition, results for most of the other elements are slightly off the expected values. These results were also affected by a problem with data storage and manipulation in the computer. This problem was corrected during June 1984 . The J-13 analyses run on $6 / 13 / 84$ give correct results for all elements (Table $1 b$ ).

Control blanks run on $6 / 22 / 84$ give the expected results for J-13 except for No.6. The results for most elements in this sample are erratic and indicate hardware problems during the analysis. This sample has been excluded from the data set used to obtain the average for $\mathrm{J}-13$ samples run on 6/22/84.

A summary of all J-13 control blank analyses run on the polychrometer ICP are given in Table 1d. The summary does not include the set run on 5/17/84 since these analyses are suspect for all elements. Details of analyses for the period from July 1983 through March 1984 are given in Oversby (1984).

During the course of these experiments a new monochrometer ICP was brought on-line. To check on the precision and accuracy of the new instrument, a split of each of the solution samples for the rock-water matrix at $120^{\circ} \mathrm{C}$ was analyzed on both the new and old ICP units. A series of control blanks of J-13 water was submitted to the new ICP facility along with the solution samples. Data for the J-13 analyses are given in Table 1e; results for sample solutions are compared with those obtained on the polychrometer $1 \mathrm{CP}^{\mathrm{P}}$ in Appendix A. Results for most elements on the monochrometer ICP are slightly higher than those obtained from the polychrometer unit. The exception is boron, which is lower in the new ICP results.

Anion analyses were performed using a Dionex Model 2110i Ion Chromatograph with a "fast run" AS4 separator column and an anion fiber suppressor. Detection limits are $0.1 \mathrm{ppm}$ for $\mathrm{Cl}^{-}$and $\mathrm{F}^{-}$and $0.2 \mathrm{ppm}$ for $\mathrm{NO}_{3}^{-}$and $\mathrm{SO}_{\overline{4}}^{\overline{4}}$. Alkalinity measurements were made using a Technicon Autoanalyzer, an automated version of the standard total alkalinity titration. This method measures the sum of the $\mathrm{OH}^{-}, \mathrm{HCO}_{3}^{-}, \mathrm{CO}_{3}^{-}$, and any other titratable anions (such as $\mathrm{H}_{3} \mathrm{SiO}_{4}^{-}$) in solu- 
Table 1. Data for ICP analyses of J-13 water samples. Concentration in ppm.

a. Four J-13 water samples run on 5/17/84 - control blanks:

\begin{tabular}{cccccccccc}
\hline No. & Al & B & Fe & Si & C & K & MB & Na & Li \\
\hline 1 & 0.006 & 0.145 & 0.006 & 28.7 & 14.2 & 3.2 & 2.05 & 49.4 & 0.040 \\
2 & $<0.002$ & 0.145 & 0.003 & 28.7 & 14.2 & 2.8 & 2.06 & 49.6 & 0.039 \\
3 & $<0.002$ & 0.148 & 0.011 & 28.5 & 14.1 & 3.0 & 2.07 & 50.8 & 0.039 \\
4 & $<0.002$ & 0.146 & $<0.001$ & 28.8 & 14.2 & 2.5 & 2.08 & 50.6 & 0.039 \\
& & & & & & & & & \\
Average & 0.002 & 0.146 & 0.005 & 28.7 & 14.2 & 2.9 & 2.07 & 50.1 & 0.039 \\
Std dev. & 0.003 & 0.001 & 0.004 & 0.11 & 0.04 & 0.3 & 0.011 & 0.61 & 0.0004
\end{tabular}

b. Six J-13 water samples run on 6/13/84, known by analyst to be J-13.

\begin{tabular}{cccccccccc} 
No. & Al & B & Fe & Si & C & K & Mg & Na & Li \\
\hline 1 & bdl & 0.137 & $<0.002$ & 27.3 & 12.7 & 5.05 & 1.92 & 44.2 & 0.041 \\
2 & bdl & 0.141 & 0.002 & 27.4 & 12.8 & 4.94 & 1.92 & 44.8 & 0.042 \\
3 & bdl & 0.137 & 0.002 & 27.2 & 12.7 & 5.17 & 1.91 & 44.6 & 0.042 \\
4 & bdl & 0.137 & 0.003 & 27.4 & 12.8 & 5.30 & 1.92 & 45.1 & 0.042 \\
5 & bdl & 0.139 & 0.012 & 27.3 & 12.8 & 4.56 & 1.92 & 45.0 & 0.042 \\
6 & bdl & 0.137 & 0.006 & 27.2 & 12.8 & 5.34 & 1.92 & 44.6 & 0.042 \\
& & & & & & & & & \\
Average & & 0.138 & 0.005 & 27.3 & 12.8 & 5.06 & 1.92 & 44.7 & 0.042 \\
Std dev. & & 0.002 & 0.004 & 0.08 & 0.05 & 0.26 & 0.004 & 0.30 & 0.0004
\end{tabular}

c. Six J-13 water samples run on $6 / 22 / 84$ - control blanks.

\begin{tabular}{|c|c|c|c|c|c|c|c|c|c|}
\hline No. & Al & B & Fe & $\mathbf{S i}$ & $\mathrm{Ca}$ & $k$ & $\mathbf{M i g}$ & $\mathrm{Na}$ & $\mathbf{L}$ \\
\hline 1 & 0.022 & 0.135 & 0.012 & 26.6 & 12.5 & 4.94 & 1.71 & 44.0 & 0.042 \\
\hline 2 & 0.021 & 0.138 & 0.010 & 26.6 & 12.5 & 4.60 & 1.90 & 44.0 & 0.041 \\
\hline $\mathbf{3}$ & 0.017 & 0.138 & 0.014 & 26.8 & 12.7 & 5.28 & 1.92 & 44.9 & 0.043 \\
\hline 4 & 0.021 & 0.138 & 0.026 & 26.6 & 12.6 & 5.37 & 1.92 & 44.7 & 0.043 \\
\hline 5 & 0.012 & 0.134 & 0.013 & 26.5 & 12.7 & 4.41 & 1.91 & 44.9 & 0.042 \\
\hline 6 & 0.032 & 0.140 & 0.069 & 27.3 & 12.3 & 4.02 & 1.86 & 43.3 & 0.041 \\
\hline Average & 0.019 & 0.137 & 0.015 & 26.6 & 12.6 & 4.92 & 1.91 & 44.5 & 0.042 \\
\hline Sid dev. & 0.004 & 0.002 & 0.006 & 0.10 & 0.09 & 0.37 & 0.007 & 0.41 & 0.001 \\
\hline
\end{tabular}

d. Average of all data for J-13 cation analyses, excluding 5/17/84.

\begin{tabular}{|c|c|c|c|c|c|c|c|c|c|}
\hline Date & AI & B & Fe & $\mathbf{S i}$ & $\mathrm{Ca}$ & $\mathbf{K}$ & $\mathbf{M g}$ & $\mathbf{N a}$ & $\mathbf{L i}$ \\
\hline $7 / 19 / 83$ & 0.009 & 0.121 & 0.009 & 27.0 & 11.9 & 5.46 & 1.88 & 43.4 & \\
\hline $8 / 4 / 83$ & 0.003 & & 0.002 & 26.2 & 13.5 & 5.19 & 2.07 & 44.9 & \\
\hline 9/13/83 & 0.001 & 0.120 & 0.002 & 27.0 & 12.8 & 4.54 & 1.91 & 43.3 & \\
\hline $10 / 24 / 83$ & 0.013 & 0.125 & 0.008 & 26.9 & 13.3 & 4.89 & 1.93 & 43.6 & \\
\hline $12 / 6 / 83$ & 0.012 & & 0.004 & 27.5 & 12.5 & 5.09 & & 45.5 & \\
\hline $12 / 16 / 83$ & 0.012 & & $<0.002$ & 27.5 & 12.5 & 5.09 & & 45.5 & \\
\hline Av2/15/84 & 0.040 & & 0.015 & 26.2 & 12.2 & 4.73 & 1.90 & 41.2 & \\
\hline $3 / 7 / 64$ & 0.009 & & 0.004 & 27.8 & 10.5 & 5.67 & 1.86 & 43.3 & \\
\hline Av3/7/84 & 0.011 & & 0.004 & 27.0 & 13.0 & 5.51 & 1.92 & 43.4 & \\
\hline Av6/1s/84 & $<0.002$ & 0.138 & 0.005 & 27.3 & 12.8 & 5.10 & 1.92 & 44.7 & 0.042 \\
\hline Av6/22/84 & 0.019 & 0.137 & 0.015 & 26.6 & 12.6 & 4.92 & 1.91 & 44.5 & 0.042 \\
\hline Average & 0.012 & 0.128 & 9.0 .06 & 27.0 & 12.5 & 5.11 & 1.92 & 43.9 & 0.042 \\
\hline Std. dev. & 0.010 & 0.008 & 0.005 & 0.49 & 0.77 & 0.32 & 0.06 & 1.19 & \\
\hline
\end{tabular}


Table 1. (Continued)

\begin{tabular}{|c|c|c|c|c|c|c|c|}
\hline No. & A1 & B & & 5 & $C_{0}$ & & \\
\hline & & & & & & & \\
\hline 1 & Dal- & 0.11 & 0.028 & 27.5 & 13.8 & 2.11 & 51.3 \\
\hline 2 & bdl & 0.10 & 0.026 & 27.0 & 13.3 & 2.11 & 46.8 \\
\hline 3 & bdl & 0.11 & 0.030 & 26.7 & 13.8 & 2.08 & 48.7 \\
\hline 4 & bdl & 0.12 & 0.025 & 26.7 & 13.9 & 2.10 & 46.5 \\
\hline Average & $\mathrm{dl}^{\mathrm{b}}=.028$ & 0.11 & 0.027 & 27.0 & 13.7 & 2.10 & 48.3 \\
\hline Std dev, & & 0.007 & 0.002 & 0.33 & 0.23 & 0.01 & 1.91 \\
\hline
\end{tabular}

"bdl $=$ below detection limit.

b $d l=$ detection limit.

Table 2. Data for anion analyses of J-13 control blanks.

a. Anions measured by ion chromatngraphy, ppm.

\begin{tabular}{rllcc}
\hline \multicolumn{1}{c}{ Date } & $\mathrm{F}^{-}$ & $\mathrm{Cl}^{-}$ & $\mathrm{NO}_{3}^{-}$ & $\mathrm{SO}_{\overline{4}}^{-}$ \\
\hline $8 / 30 / 83$ & 1.8 & 5.3 & 6.4 & 13.4 \\
$9 / 30 / 83$ & 2.3 & 6.8 & 9.3 & 19.8 \\
$\mathrm{Av3/14/84}$ & 2.3 & 6.6 & 9.0 & 18.1 \\
$\mathrm{Av3/26/84}$ & 2.4 & 7.1 & 9.2 & 18.5 \\
$3 / 30 / 84$ & 2.3 & 6.8 & 18.0 & 19.0 \\
$4 / 2 / 84$ & 2.4 & 7.0 & 9.1 & 19.0 \\
$4 / 3 / 84$ & 1.3 & 7.4 & 13.1 & 18.6 \\
$5 / 4 / 84$ & 2.3 & 6.9 & 7.0 & 18.4 \\
$5 / 4 / 84$ & 2.3 & 6.9 & 6.4 & 18.5 \\
$5 / 10 / 84$ & 2.2 & 6.9 & 5.4 & 18.4 \\
& & & & \\
Average & 2.2 & 6.8 & 9.3 & 18.2 \\
Std dev. & 0.33 & 0.53 & 3.57 & 1.65 \\
& & & & \\
Reaverage & 2.2 & 6.9 & 9.6 & 18.7 \\
New std dev & 0.32 & 0.31 & 3.63 & 0.47
\end{tabular}

b. Alkalinity by Technicon Autoanalyzer.

\begin{tabular}{ccc}
\hline Date & $\mathrm{meq} / 1$ & $\mathrm{HCO}_{3}^{-}(\mathrm{ppm})$ \\
\hline $7 / 27 / 83$ & 2.29 & 140 \\
$8 / 5 / 83$ & 2.13 & 130 \\
$5 / 2 / 83$ & 2.16 & $1 \mathrm{j} 2$ \\
$1 / 11 / 84$ & 2.46 & $151)$ \\
$3 / 13 / 84$ & 2.10 & $12 \mathrm{~b}$ \\
Average & 2.23 & $13 \mathrm{~b}$ \\
Std dev. & 0.13 & 8.1 \\
\hline
\end{tabular}

tions. For the $\mathrm{pH}$ range and silicon concentrations of samples resulting from these experiments, the contribution of silica species to alkalinity should be minor.

Table 2 gives a summary of results for anion and alkalinity measurements on control blank samples of J-13 water. Results obtained through $3 / 26 / 84$ have been previously reported and discussed by Oversby (1984). Data for anion analyses on $8 / 30 / 83$ are systematically low and have been eliminated to obtain the average value for J-13 (labelled Reaverage in Table 2a). Analyses for nitrate were erratic during the period from $3 / 30 / 84$ through $5 / 10 / 84$. The reason for this problem is being investigated. Only four samples for winich results are reported here were analyzed during 1984. 
The control blank samples are run in the same sample sets as the solutions from the rock-water hydrothermal reaction experiments. The precision of the analytical results for the control blanks provides a good measure of the precision of theanalytical results for the experimental solutions.
The standard deviation quoted is that of the population; for a single analysis the appropriate value would be slightly higher, the difference amounting to a few percent of the value of the standard deviation in most cases.

\section{Results and Discussion}

\section{Composition of the Caliche Component}

The rock sampies used in the experiments were pretreated to remove the readily solublesalts that are associated with rock material collected from surface outcrops near Yucca Mountain. The composition of soluble salts removed from the Fran Ridge outcrop Topopah Spring tuff used in previous experiments was reported by Oversby (1984). Rock used in the present experiments was from a companion split of the same crushing and, as such, was expected to have the same quantity and type of soluble material. The rinse solution used to pretreat the $120^{\circ} \mathrm{C}$ samples was $48 \mathrm{ml}$ of J-13 water in all cases. Table 3 gives the anion concentrations found in the room temperature rinsing step; data for anion concentrations from the overnight cooked rinse at $120^{\circ} \mathrm{C}$ are given in Table 4 .

There is no indication that any fluoride or carbonate material is released to solution during either of the pretreatment rinsing steps. In fact, alkalinity decreases by approximately $10 \%$ during the room temperature rinse and remains essentially constant or decreases slightly during the ccoked rinse.

The dominant anion components of the soluble material are nitrate and sulfate. There is also a chloride component, but it is present in much lower amounts. Anion concentrations in the rinse solutions are approximately linear with sample weight, as can be seen in Fig. 2, which plots the averages for chloride, nitrate, and sulfate concentrations from room temperature,rinse solutions as a function of rock sample weight: This is the behavior to be expected if the anions are due to complete solution of a readily soluble phase or phases.

The quantity of anions released during the overni, ht cooked rinse is substantially smaller. A portion of these anions is undoubtedly due to retention of some of the room temperature rinse solution on the rock when that solution was removed by decantation.
The total amount of anions removed from the rock used in these experiments is slightly higher than the anions found on rock material from split $A-4$, which was used in the 90 and $150^{\circ} \mathrm{C}$ experiments (Oversby, 1984). The difference in amount is very small and, as will be seen below, correlates with a slightly greater amount of calcium, potassium, and sodium in the rinse solutions from split A-3 material.

Data for the $\mathrm{pH}$ of room temperature and $120^{\circ} \mathrm{C}$ rinse solutions are given in Table 5 . The $\mathrm{pH}$ of the rinse solutions is systematically higher than that of J-13 water, and shows a positive correlation with rock sample weight. None of the anion components identified in the rinse solutions is a weak acid; therefore, the change in pH must be due to a component analyzed by ICP and reported as a cation.

Tables 6 through 12 give data for rinse solutions measured by $1 \mathrm{CP}$. The couked rinse data are affected by reaction with the rock at $120^{\circ} \mathrm{C}$, and therefore cannot be used to unambiguously identify the nature of the soluble component. Data for aluminum in the room temperature rinse solutions are slightly erratic for the 1.6- and 3.2-g samples; however, total aluminum releäse is small in all cases and is slightly less than that found for split A-4 (Oversby, 1984).

Boron release (Table 7) is linear with sample weight in both the room temperature and cooked rinse solutions. Boron can form a weak acid; this may be the cause of the $\mathrm{pH}$ change found in the rinse solutions. Boron was not a component of the soluble material associated with split A-4 (Oversby, 1984).

Iron concentrations (Table 8) are essentially constant at j-13 values for both the room temperature and cooked rinse solutions. Silicon (Table 9) is slightly lower than the J-13 concentration in the room temperature rinse, while it is higher in the cooked rinse solution due to reaction of the water with the rock at $120^{\circ} \mathrm{C}$. Both of these results are the 
Table 3. Anion concentrations in ppm from room temperature rinse solutions. Sample identification is final run time followed by sample weight in grams.

\begin{tabular}{|c|c|c|c|c|c|c|}
\hline \multirow[b]{2}{*}{ Sample ID } & \multirow[b]{2}{*}{$\mathbf{F}^{-}$} & \multirow[b]{2}{*}{$\mathrm{CI}^{-}$} & \multirow[b]{2}{*}{$\mathrm{NO}_{3}$} & \multirow[b]{2}{*}{$\mathrm{SO}_{4}$} & \multicolumn{2}{|c|}{ Alkalinily } \\
\hline & & & & & meq $/ 1$ & $\mathrm{HCO}_{3}$ (ppm) \\
\hline$J-13$ & 2.2 & 6.9 & 9.6 & 18.7 & 2.23 & 136 \\
\hline $1-0.4$ & 2.4 & 8.9 & 19.3 & 28.0 & 2.03 & 124 \\
\hline $3-0.4$ & 2.2 & 8.9 & 18.8 & 21.9 & 2.04 & 124 \\
\hline $6-0.4$ & 2.2 & 8.4 & 18.5 & 25.6 & 2.10 & 128 \\
\hline $12-0.4$ & 2.2 & 8.3 & 19.4 & 25.1 & 1.99 & 121 \\
\hline 24-0.4 & 2.2 & 8.5 & 19.0 & 25.5 & 2.01 & 123 \\
\hline $36-0.4$ & 2.4 & 8.7 & 19.5 & 26.5 & 2.10 & 128 \\
\hline $48-0.4$ & 2.2 & 7.9 & 19.3 & 28.4 & 1.95 & 119 \\
\hline $60-0.4$ & 2.1 & 8.2 & 16.4 & $\mathbf{2 5 . 0}$ & 2.09 & 127 \\
\hline $72-0.4$ & 2.3 & 8.5 & 19.9 & 26.9 & 2.02 & 123 \\
\hline Average & 2.2 & 8.5 & 18.9 & 25.9 & $2.0 \mathrm{~A}$ & 124 \\
\hline Sid dev. & 0.10 & 0.31 & 0.96 & 1.81 & 0.05 & 3 \\
\hline $1-0,3$ & 2.1 & 10.6 & 29.4 & 35.5 & 2.13 & 130 \\
\hline $3-0.8$ & 2.2 & 10.6 & 29.2 & 33.4 & 1.97 & 120 \\
\hline $6-0.8$ & 2.2 & 10.1 & 28.1 & 32.8 & 2.09 & 127 \\
\hline $12-0.8$ & 2.3 & 9.8 & 29.3 & 33.5 & 2.09 & 127 \\
\hline $24-0.8$ & 2.2 & 9.8 & 28.7 & 33.0 & 2.01 & 123 \\
\hline $36-0.8$ & 2.1 & 10.0 & 27.5 & 32.1 & 2.10 & 128 \\
\hline $48-0.8$ & 2.2 & 20.4 & 28.6 & 35.6 & 1.98 & 121 \\
\hline $60-0.8$ & 2.2 & 10.7 & 29.6 & 35.8 & 2.09 & 127 \\
\hline $72-0.8$ & 2.3 & 10.0 & 29.5 & 32.2 & 1.99 & 121 \\
\hline Average & 2.2 & 10.2 & 28.9 & 33.8 & 2.05 & 125 \\
\hline Std dev. & 0.07 & 0.34 & 0.67 & 1.40 & 0.06 & 4 \\
\hline $1-1.6$ & 2.2 & 13.4 & 48.0 & 46.7 & 1.99 & 121 \\
\hline $3-1.6$ & 2.3 & 13,4 & 48.1 & 45.8 & 2.06 & 124 \\
\hline 6-1.6 & 2.1 & 12.4 & 49.6 & 43.9 & 2.13 & 130 \\
\hline $12-1.6$ & 2.3 & 12.9 & 49.3 & 46.5 & 1.94 & 118 \\
\hline 24-1.i & 2.3 & 12.8 & 48.0 & 45.2 & 2.09 & 127 \\
\hline $36-1.6$ & 2.1 & 12.8 & 44.1 & 43.5 & 2.05 & 125 \\
\hline 48-1.6 & 2.2 & 13.1 & 45.9 & $46 . \overline{1}$ & 2.00 & 127 \\
\hline $60-1.6$ & 2.2 & 13.4 & 48.3 & 47.1 & 2.10 & 128 \\
\hline $72-1.6$ & 2.3 & 12.7 & A5. B & 45.5 & 2.11 & 129 \\
\hline Average & 2.2 & 13.0 & $\$ 6.9$ & 45.6 & 2.106 & 126 \\
\hline Std dev. & 0.07 & 0.34 & 1.73 & 1.16 & 0.06 & 4 \\
\hline $1-3.2$ & 2.3 & 18.2 & 91.1 & 86.1 & 2.16 & 132 \\
\hline $3-3.2$ & 2.5 & 26.4 & 86.3 & 75.5 & 2.08 & 127 \\
\hline $6-3.2$ & 2.2 & 19.3 & 78.6 & 67.5 & 2.06 & 126 \\
\hline $12-3.2$ & 2.3 & 18.1 & 81.1 & 70.4 & 2.01 & 123 \\
\hline $24-3.2$ & 2.3 & 19.4 & 86.4 & 76.4 & 2.06 & 126 \\
\hline $36-3.2$ & 2,2 & 19.4 & 80.4 & 65.1 & 2.25 & 137 \\
\hline $48-3.2$ & 2.3 & 20.3 & 81.1 & 72.8 & 2.15 & 131 \\
\hline $60-3.2$ & 2.3 & 18.4 & 68.6 & a3.4 & 2.17 & 132 \\
\hline $72-3.2$ & 1.3 & 17.8 & & 74.8 & 2.13 & 130 \\
\hline $72-3.28$ & 2.3 & 17.1 & 78.1 & 67.3 & & \\
\hline Average & 2.2 & 19.4 & 81.3 & 73.9 & 2.12 & 129 \\
\hline Std dev. & 0.31 & 2.49 & 6.03 & 6.51 & 0.07 & 4 \\
\hline
\end{tabular}


Table 4. Anion concenirations in ppm from rvernight cooked rinse soletion. Sample idemtification in final run time followed hy sample weight in grams.

\begin{tabular}{|c|c|c|c|c|c|c|}
\hline \multirow[b]{2}{*}{ Sample ID } & \multirow[b]{2}{*}{$\mathbf{F}^{-}$} & \multirow[b]{2}{*}{$\mathbf{C l}^{-}$} & \multirow[b]{2}{*}{$\mathrm{NO}_{3}^{-}$} & \multirow[b]{2}{*}{$\mathrm{SO}_{4}^{-}$} & \multicolumn{2}{|c|}{ 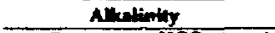 } \\
\hline & & & & & 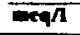 & $\mathrm{XCO}_{3} / 4 \mathrm{~d}$ \\
\hline J-13 & 2.2 & 6.9 & 9.6 & 18.7 & 2.23 & $13 \%$ \\
\hline $1-0.4$ & 2.3 & 7.9 & 11.5 & 20.9 & 2.05 & 125 \\
\hline $3-0.4$ & 2.2 & 7.1 & 5.1 & 18.4 & 2.06 & 126 \\
\hline $6-0.4$ & 2.2 & 7.0 & 10.5 & 75.7 & 2.08 & 127 \\
\hline $12-0.4$ & 2.3 & 7.3 & 10.9 & 19.6 & 2.11 & 129 \\
\hline $24-0.4$ & 2.3 & 7.1 & 10.8 & 18.9 & 2.09 & 127 \\
\hline $36-0.4$ & 2.3 & 7.2 & 11.1 & 14.5 & 2.00 & 127 \\
\hline $48-0.4$ & 2.3 & 8.1 & 11.6 & 21.3 & 2.05 & 125 \\
\hline $00-0.4$ & 2.0 & 6.2 & 9.4 & 16.8 & 2.17 & 132 \\
\hline $72-0.4$ & 2.2 & 7.2 & 10.7 & 19.5 & 2.18 & 133 \\
\hline Average & 2.2 & 7.2 & 10.2 & 19.3 & 2.10 & 128 \\
\hline Std dev. & 0.09 & 0.51 & 1.89 & 1.26 & 0.05 & 3 \\
\hline $1-0.8$ & 2.3 & 8.3 & 19.5 & 22.0 & 2.13 & 130 \\
\hline $3-0.8$ & 2.2 & 7.5 & 10.9 & 18.9 & $\cdot \mathbf{2 . 0 6}$ & 126 \\
\hline$G-0.8$ & 2,0 & 6.8 & 11.3 & 18.1 & 2.22 & 135 \\
\hline $12-0.8$ & 2.3 & 7.7 & 13.2 & 13.9 & 2.18 & 133 \\
\hline $24-0.8$ & 3.4 & 7.7 & 13.0 & $32:$ & 2.11 & 129 \\
\hline $36-0.8$ & 2.3 & 3.9 & 15.9 & 21.7 & 2.20 & 134 \\
\hline $48-0.8$ & 2.2 & 8.5 & 26.6 & 39:? & 2.13 & 130 \\
\hline $60-0.8$ & 2.5 & 8.4 & 15.4 & 23.8 & 2.18 & 133 \\
\hline $72-0.8$ & 2.3 & 7.6 & 13.0 & 20.0 & 2.18 & 133 \\
\hline Average & 2.4 & 7.8 & 15.0 & 23.4 & 2.15 & 131 \\
\hline Std dev. & 0.38 & 0.50 & 5.03 & 7.39 & 0.05 & 3 \\
\hline $1-1.6$ & 2.3 & 9.0 & 17.0 & 24.0 & 2.13 & 130 \\
\hline $3-1.6$ & 2.3 & 8.3 & 14.1 & 21.5 & 2.07 & 126 \\
\hline $6-1.6$ & 2.4 & 8.6 & 17.4 & 23.2 & 2.14 & 131 \\
\hline $12-1.6$ & 2.3 & 8.6 & 16.9 & 23.0 & 2.19 & 134 \\
\hline $24-1.6$ & 2.3 & 8.3 & 16.9 & 22.7 & 2.19 & 134 \\
\hline $36-1.6$ & 2.5 & B.7 & 18.4 & 24.4 & 2.15 & $13 I$ \\
\hline $48-1.6$ & 2.2 & 8.9 & 16.4 & 23.4 & 2.22 & 135 \\
\hline $60-1.6$ & 2.3 & B.1 & 16.0 & 22.3 & 2.18 & 133 \\
\hline $72-16$ & 2.5 & $\mathbf{8 . 8}$ & 18.3 & 24.0 & 2.23 & 136 \\
\hline Average & 2.3 & 8.6 & 16.8 & 2.2 & 2.17 & 132 \\
\hline Std dev. & 0.10 & 0.28 & 1.22 & 0.87 & 0.05 & 3 \\
\hline $1-3.2$ & 2.3 & 10.8 & 26.8 & 31.6 & 2.21 & 135 \\
\hline $3-3.2$ & 2.3 & 9.9 & 23.0 & 25.7 & 2.07 & 126 \\
\hline $6-3.2$ & 2.1 & 10.0 & 23.7 & 27.4 & 2.26 & 138 \\
\hline $12-3.2$ & 2.4 & 10.5 & 27.6 & 298 & 2.18 & 133 \\
\hline $24-3.2$ & 2.4 & 10.1 & 27.5 & 27.3 & 2.11 & 129 \\
\hline $36-3.2$ & 2.4 & 11.2 & 28.9 & 33.3 & 2.18 & 133 \\
\hline$s 8-3.2$ & 2.4 & 10.7 & 25.4 & 29.8 & 2.23 & 136 \\
\hline $48-3.2 \mathrm{~B}$ & 2.3 & 10.4 & 25.9 & 26.7 & & \\
\hline $60-3.2$ & 2.5 & 11,0 & 26.8 & 30.5 & 2.23 & 136 \\
\hline $72-3.2$ & 2.4 & 10.6 & 26.0 & 30.9 & 2.20 & 134 \\
\hline Average & 2.4 & 10.5 & $26 . ?$ & 29.3 & 2.19 & 133 \\
\hline Std dev. & 0.10 & 0.41 & $1 . j 9$ & 2.39 & 0.06 & 3 \\
\hline
\end{tabular}




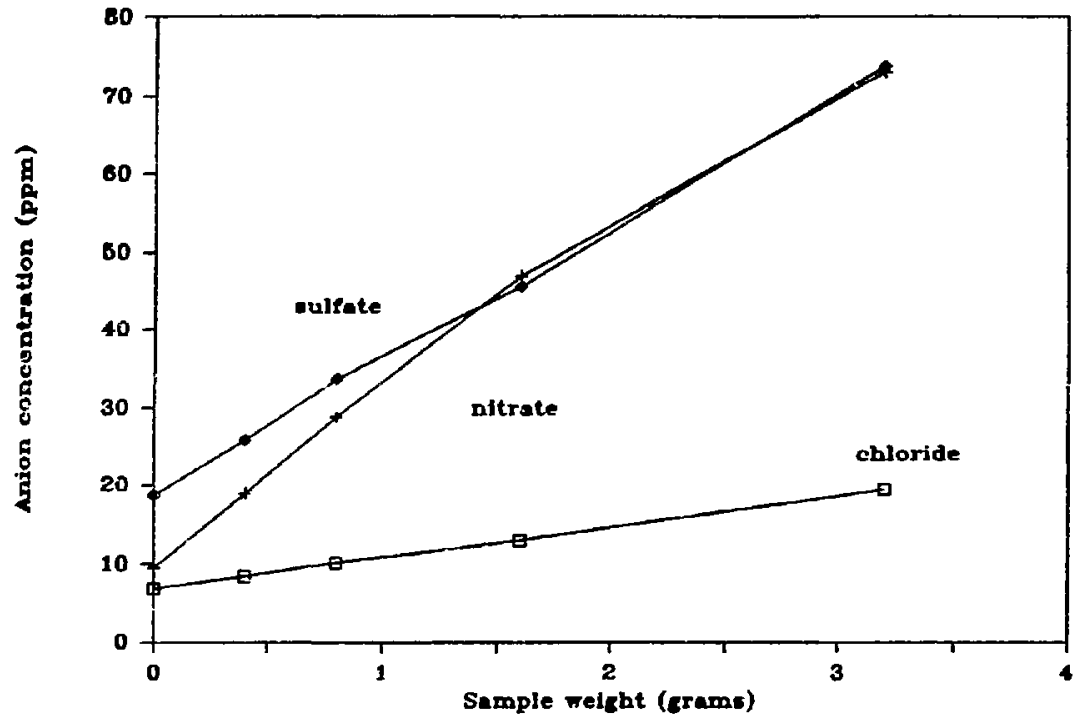

Figure 2. Concentrations of anions in protreatment room temperature rinse solutions (rable 3) plotted as a function of sample weight.

Table 5. $\mathrm{pH}$ of solutions from room temperature rinse and overnight-cooked risse pretreatment. Initial J-13 $\mathrm{pH}=7.6$.

\begin{tabular}{|c|c|c|c|c|c|}
\hline & \multirow{2}{*}{$\begin{array}{c}\text { Rinse } \\
\text { sample no. }\end{array}$} & \multicolumn{4}{|c|}{ Weight (grams) } \\
\hline & & 0.40 & 0.80 & 1.60 & 3.20 \\
\hline & 1 & 8.21 & 8.28 & 8.37 & 8.90 \\
\hline & 3 & 8.14 & 8.12 & 8.20 & 8.23 \\
\hline & 6 & 8.09 & 8.18 & 6.25 & 8.29 \\
\hline & 12 & 8.13 & 8.23 & 8.34 & 8.40 \\
\hline & 24 & 8.12 & 8.24 & 8.33 & 8.35 \\
\hline & 36 & $\mathbf{n m}^{2}$ & $\mathrm{~nm}$ & $\mathrm{~nm}$ & nm \\
\hline & 48 & 8.19 & 8.28 & 8.34 & 8.42 \\
\hline & 60 & 8.05 & 8.24 & 8.30 & 8.42 \\
\hline & 72 & $\mathrm{~nm}$ & nm & nm & nm \\
\hline & A verage & 8.13 & 8.22 & 8.30 & B.36 \\
\hline & std dev. & 0.06 & 0.05 & 0.06 & 0.07 \\
\hline & \multicolumn{5}{|l|}{ Cooked rinse } \\
\hline & $\mathbf{1}$ & 8.22 & 8.28 & 8.34 & 8.32 \\
\hline & 3 & 8.14 & 8.24 & 8.25 & 8.26 \\
\hline & 6 & B.08 & B.13 & 6.20 & 8.22 \\
\hline & 12 & 8.16 & 8.25 & 8.29 & 8.31 \\
\hline & 24 & 8.16 & 8.24 & B.29 & 8.34 \\
\hline & 36 & $\mathbf{n m}$ & $\mathbf{n m}$ & $\mathbf{n m}$ & $\mathbf{n m}$ \\
\hline$\cdot$ & 48 & 8.12 & 8.18 & 8.27 & 8.33 \\
\hline & 60 & 8.30 & 8.27 & 8.19 & 8.21 \\
\hline & 72 & $\mathbf{n m}$ & nm & $\mathrm{nm}$ & $\mathbf{n m}$ \\
\hline & Average & 8.17 & 8.23 & 8.26 & 8.28 \\
\hline & Std dev. & 0.07 & 0.05 & 0.05 & 0.65 \\
\hline
\end{tabular}


Table 6. Aluminum concentration in room tempexature rinse colutionas and overnidu-cooked rinae solutions. J-13 Al $=0.012$ ppm.

\begin{tabular}{|c|c|c|c|c|}
\hline \multirow{2}{*}{$\begin{array}{c}\text { Rinue } \\
\text { sample no. }\end{array}$} & \multicolumn{4}{|c|}{ Weight (grans) } \\
\hline & $\overline{0.40}$ & 0.00 & 1. 10 & $\overline{3.20}$ \\
\hline 1 & 0.004 & 0.031 & 0.95 & 0.136 \\
\hline 3 & 0.028 & 0.038 & 0.034 & 0.024 \\
\hline 6 & 0.014 & 0.718 & 0.019 & 0.019 \\
\hline 12 & 0.003 & 0.022 & 0.000 & 0.006 \\
\hline 24 & 0.000 & 0.025 & 0.027 & 0.000 \\
\hline 36 & 0.012 & 0.018 & 0.006 & 0.014 \\
\hline 48 & 0.033 & 0.036 & 0.140 & 0.039 \\
\hline 60 & 0.038 & 0.031 & 0.038 & 0.263 \\
\hline 72 & 0.012 & 0.010 & 0.919 & 0.009 \\
\hline Average & 0.016 & 0.024 & 0.037 & 0.057 \\
\hline Std dev. & 0.013 & 0.008 & 0.039 & 0.083 \\
\hline \multicolumn{5}{|l|}{ Cooked rinse } \\
\hline 1 & 1.67 & 1.60 & 1.34 & 1.05 \\
\hline 3 & 1.59 & 1.54 & 1.47 & 1.13 \\
\hline 6 & 1.47 & 1.46 & 1.37 & 1.12 \\
\hline $6 R$ & 1.49 & 3.48 & 1.40 & 1.14 \\
\hline 12 & 1.57 & 2.62 & 1.30 & 1.08 \\
\hline 24 & 1.48 & 1.53 & 1.26 & 1.01 \\
\hline 36 & 1.48 & 1.54 & 1.30 & 0.96 \\
\hline $36 R$ & 1.51 & 1.54 & 1.30 & 0.96 \\
\hline 48 & 1.58 & 1.53 & 1.35 & 1.03 \\
\hline 60 & 1.61 & 3.56 & 1.43 & 1.14 \\
\hline 72 & 1.59 & 1.54 & 1.37 & 1.09 \\
\hline $72 R$ & 1.62 & 1.54 & 1.38 & 1.09 \\
\hline Average & 1.56 & 1.54 & 1.36 & 1.07 \\
\hline Std dev. & 0.06 & 0.04 & 0.06 & 0.06 \\
\hline
\end{tabular}


Täble 7. Boron concentration in room temperature rinse solutions and overnight-cooked rinse solutions. J-13 B $=0.23$ ppm.

\begin{tabular}{|c|c|c|c|c|c|}
\hline \multirow{2}{*}{$\begin{array}{c}\text { Rince } \\
\text { sample no. }\end{array}$} & \multicolumn{4}{|c|}{ Weight (grams) } & \\
\hline & 0.40 & 0.80 & 1.60 & 3.20 & \\
\hline 1 & 0.118 & 0.130 & 0.133 & 0.159 & \\
\hline 3 & 0.130 & 0.137 & 0.148 & 0.168 & \\
\hline 6 & 0.102 & 0.095 & 0.102 & 0.115 & Low \\
\hline 12 & 0.115 & 0.120 & 0.135 & 0.156 & \\
\hline 24 & 0.118 & 0.122 & 0.132 & 0.163 & \\
\hline 36 & 0.059 & 0.064 & 0.070 & 0.108 & Low \\
\hline 48 & 0.119 & 0.127 & 0.140 & 0.162 & \\
\hline 60 & 0.121 & 0.117 & 0.132 & 0.163 & \\
\hline 72 & 0.046 & 0.050 & 0.057 & 0.074 & Low \\
\hline Average* & 0.120 & 0.124 & 0.137 & 0.162 & \\
\hline Std dev." & 0.005 & 0.007 & 0.006 & 0.004 & \\
\hline \multicolumn{6}{|c|}{ Cooked rinse } \\
\hline 1 & 0.130 & 0.137 & 0.156 & 0.188 & \\
\hline 3 & 0.132 & 0.147 & 0.167 & 0.213 & \\
\hline 6 & 0.081 & 0.083 & 0.107 & 0.137 & Low \\
\hline $6 R$ & 0.149 & 0.162 & 0.179 & 0.219 & \\
\hline 12 & 0.129 & 0.151 & 0.154 & 0.197 & \\
\hline 24 & 0.142 & 0.133 & 0.157 & 0.187 & \\
\hline 36 & 0.056 & 0.064 & 0.081 & 0.121 & Low \\
\hline $36 R$ & 0.150 & 0.158 & 0.177 & 0.227 & \\
\hline 48 & 0.130 & 0.139 & 0.157 & 0.196 & \\
\hline 60 & 0.131 & 0.136 & 0.156 & 0.196 & \\
\hline 72 & 0.041 & 0.050 & 0.071 & 0.112 & Low \\
\hline $72 \mathrm{R}$ & 0.152 & 0.158 & 0.183 & 0.218 & \\
\hline Average" & 0.138 & 0.146 & 0.165 & 0.205 & \\
\hline std dev." & 0.009 & 0.011 & 0.011 & 0.014 & \\
\hline
\end{tabular}

"Excluding low values. 
Table $\varepsilon$. Iron concentration in room temperature rinae solutions and overnight-cooked rime solution. $\mathrm{J}-13 \mathrm{Fe}=0.006 \mathrm{Ppm}$.

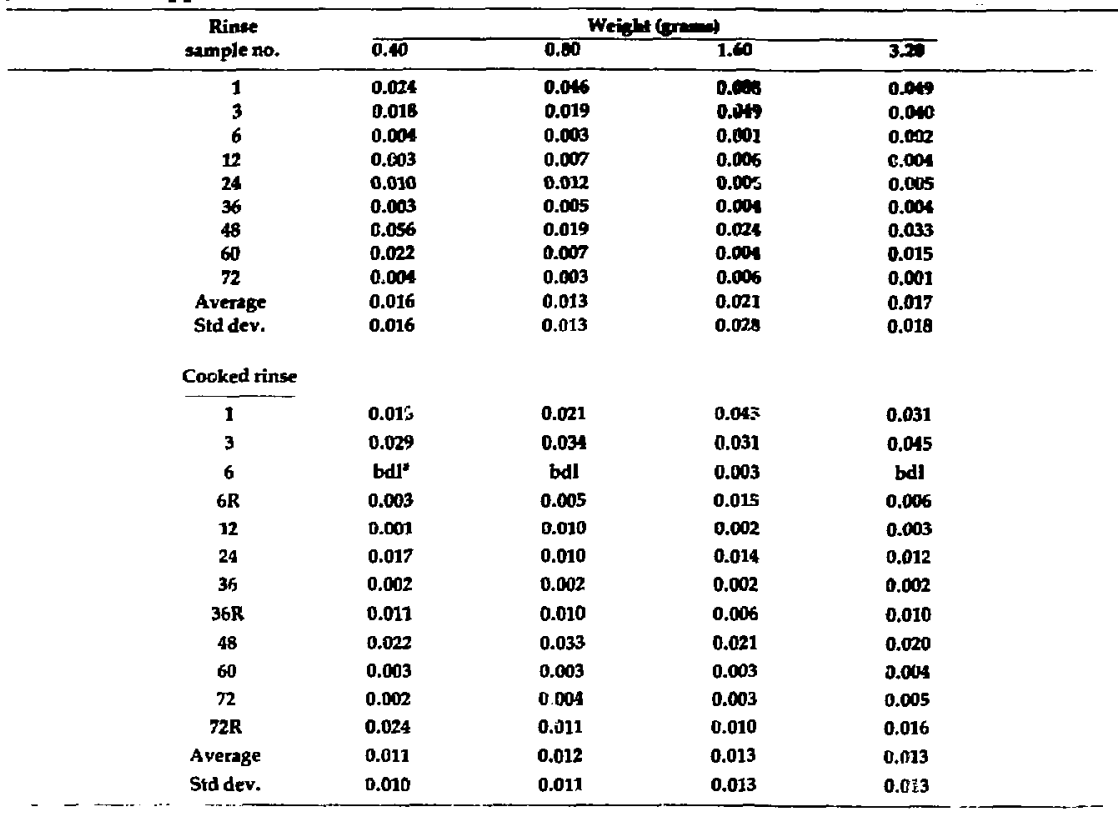

• bdl = below detection linits. 
Table 9. Silicon concentration in room tenperature rinse solutions and overnight-cooked rinse colutions. J-13 Si $=27.0$ Ppm.

\begin{tabular}{|c|c|c|c|c|}
\hline \multirow{2}{*}{$\begin{array}{c}\text { Rivese } \\
\text { sumple no. }\end{array}$} & \multicolumn{4}{|c|}{ Weight (gans) } \\
\hline & $\overline{0.40}$ & 0.80 & 1.60 & 3.20 \\
\hline 1 & 25.1 & 24.6 & 24.5 & 25.9 \\
\hline 3 & 25.7 & 25.5 & 25.8 & 25.4 \\
\hline . & 26.0 & 25.7 & 25.5 & 25.3 \\
\hline 12 & 25.2 & 24.8 & 25.1 & 24.8 \\
\hline 24 & 25.6 & 24.6 & 24.6 & 24.9 \\
\hline 36 & 26.1 & 25.7 & 25.6 & 25.4 \\
\hline 48 & 25.5 & 25.5 & 25.3 & 24.7 \\
\hline 60 & 25.2 & 24.4 & 24.2 & 25.3 \\
\hline 72 & 25.8 & 25.9 & 25.6 & 25.7 \\
\hline Avarage & 25.6 & 25.2 & 25.1 & 25.3 \\
\hline Std dev. & 0.34 & 0.55 & 0.54 & 0.38 \\
\hline \multicolumn{5}{|l|}{ Cooked rinse } \\
\hline 1 & 37.6 & 40.4 & 44.2 & 48.3 \\
\hline 3 & 37.5 & 40.2 & 46.1 & 52.2 \\
\hline 6 & 36.7 & 39.2 & 44.5 & 51.0 \\
\hline $6 R$ & 36.5 & 39.1 & 44.4 & 51.2 \\
\hline 12 & 36.9 & 40.9 & 42.8 & 50.4 \\
\hline 24 & 37.7 & 37.8 & 43.2 & 46.3 \\
\hline 36 & 36.9 & 40.0 & 44.1 & 48.9 \\
\hline $36 R$ & 36.8 & 39.6 & 43.8 & 49.1 \\
\hline 48 & 56.1 & 39.8 & 43.2 & 48.0 \\
\hline 60 & 36.0 & 38.4 & 43.1 & 48.3 \\
\hline 72 & 37.3 & 39.8 & 43.8 & 50.3 \\
\hline $72 R$ & 36.9 & 39.5 & 43.6 & 50.6 \\
\hline Average & 36.9 & 39.5 & 43.9 & 49.6 \\
\hline Std dev. & 0.53 & 0.84 & 0.84 & 1.62 \\
\hline
\end{tabular}


Table 10. Calcium concentration in room temperature rinue solutions and overnight-cooked river solutions. J-13 $\mathrm{Ca}=12.5 \mathrm{ppm}$.

\begin{tabular}{|c|c|c|c|c|}
\hline \multirow{2}{*}{$\begin{array}{c}\text { Ringe } \\
\text { sample no. }\end{array}$} & \multicolumn{4}{|c|}{ Weight (grams) } \\
\hline & $\overline{0.40}$ & 0.00 & 1.60 & 3.20 \\
\hline 1 & 16.0 & 19.5 & 23.6 & 45.2 \\
\hline 3 & 17.0 & 21.2 & 29.7 & 46.0 \\
\hline 6 & 16.4 & 19.4 & 27.4 & 43.2 \\
\hline 12 & 15.4 & 20.2 & 28.5 & 42.1 \\
\hline 24 & 17.3 & 39.3 & 27.5 & 45.1 \\
\hline 36 & 16.1 & 19.6 & 27.9 & 41.8 \\
\hline 48 & 15.5 & 19.6 & 27.1 & $\$ 1.4$ \\
\hline 60 & 15.6 & 19.3 & 27.2 & 43.3 \\
\hline 72 & 16.0 & 21.1 & 27.6 & 44.8 \\
\hline Average & 16.1 & 19.9 & 27.9 & 43.7 \\
\hline Std dev. & 0.58 & 0.71 & 0.80 & 1.58 \\
\hline \multicolumn{5}{|l|}{ Cooked rinse } \\
\hline 1 & 10.6 & 10.8 & 10.8 & 11.1 \\
\hline 3 & 11.1 & 10.8 & 10.3 & 11.1 \\
\hline 6 & 11.0 & 10.9 & 11.2 & 10.5 \\
\hline $6 R$ & 11.5 & 11.5 & 11.2 & 11.0 \\
\hline 12 & 11.9 & 13.0 & 10.7 & 12.2 \\
\hline 29 & 14.0 & 10.9 & 12.5 & 10.5 \\
\hline 36 & 12.0 & 12.2 & 11.6 & 13.7 \\
\hline $36 \mathrm{R}$ & 12.4 & 12.3 & 12.1 & 14.4 \\
\hline 48 & 10.0 & 10.9 & 10.1 & 10.4 \\
\hline 60 & 11.0 & 11.3 & 10.5 & 11.1 \\
\hline 72 & 12.1 & 11.7 & 11.9 & 11.4 \\
\hline $72 R$ & 12.2 & 11.9 & 11.8 & 11.9 \\
\hline Average & 11.6 & 11.5 & 11.2 & 11.6 \\
\hline Std dev. & 0.99 & 0.63 & 0.73 & 1.21 \\
\hline
\end{tabular}


Table 11. Magnesium concentration in room temperature rinse solutions and overnight-cooked rinse solutions. J-13 $\mathrm{Mg}=1.92 \mathrm{ppm}$.

\begin{tabular}{|c|c|c|c|c|}
\hline \multirow{2}{*}{$\begin{array}{c}\text { Rinse } \\
\text { sample no. }\end{array}$} & \multicolumn{3}{|c|}{ Weight (grams) } & \multirow[b]{2}{*}{$\overline{3.20}$} \\
\hline & $0.40^{\circ}$ & 0.80 & 1.60 & \\
\hline 1 & 1.79 & 1.93 & 2.16 & 2.40 \\
\hline 3 & 1.83 & 1.89 & 2.10 & 2.37 \\
\hline 6 & 1.79 & 1.87 & 2.02 & 2.33 \\
\hline 12 & 1.76 & $\mathbf{1 . 8 2}$ & 1.97 & 2.23 \\
\hline 24 & 1.81 & $1.8 A$ & 1.98 & 2.26 \\
\hline 36 & 1.82 & 1.86 & 2.01 & 2.30 \\
\hline 48 & 1.84 & 1.88 & 2.02 & 2.33 \\
\hline 60 & 1.78 & 1.78 & 1.92 & 2.29 \\
\hline 72 & 1.82 & 1.88 & 2.04 & 2.34 \\
\hline Average & 1.80 & 1.86 & 2.02 & 2.32 \\
\hline Std dev. & 0.02 & 0.04 & 0.07 & 0.05 \\
\hline \multicolumn{5}{|c|}{ Cooked rinse } \\
\hline 1 & 0.29 & 0.26 & 0.32 & 0.31 \\
\hline 3 & 0.19 & 0.21 & 0.18 & 0.26 \\
\hline 6 & 0.27 & 0.27 & 0.25 & 0.23 \\
\hline $\mathbf{G R}$ & 0.28 & 0.28 & 0.27 & 0.24 \\
\hline 12 & 0.26 & 0.27 & 0.26 & 0.25 \\
\hline 24 & 0.36 & 0.24 & 0.33 & 0.31 \\
\hline 36 & 0.27 & 0.21 & 0.24 & 0.29 \\
\hline $36 R$ & 0.26 & 0.21 & 0.24 & 0.29 \\
\hline 48 & 0.27 & 0.30 & 0.26 & 0.26 \\
\hline fis & 0.27 & 0.24 & 0.21 & $\mathbf{0 . 2 3}$ \\
\hline 72 & 0.24 & 0.24 & 0.23 & 0.20 \\
\hline 72R & 0.24 & 0.24 & 0.23 & 0.20 \\
\hline Average & 0.27 & 0.25 & 0.25 & 0.25 \\
\hline Std dev. & 0.04 & 0.03 & 0.04 & 0.04 \\
\hline
\end{tabular}


Table 12. Potassium concentration in room temperature rinse solutions and overnight-cooked firise solutions. J-13 K = 5.1 ppm.

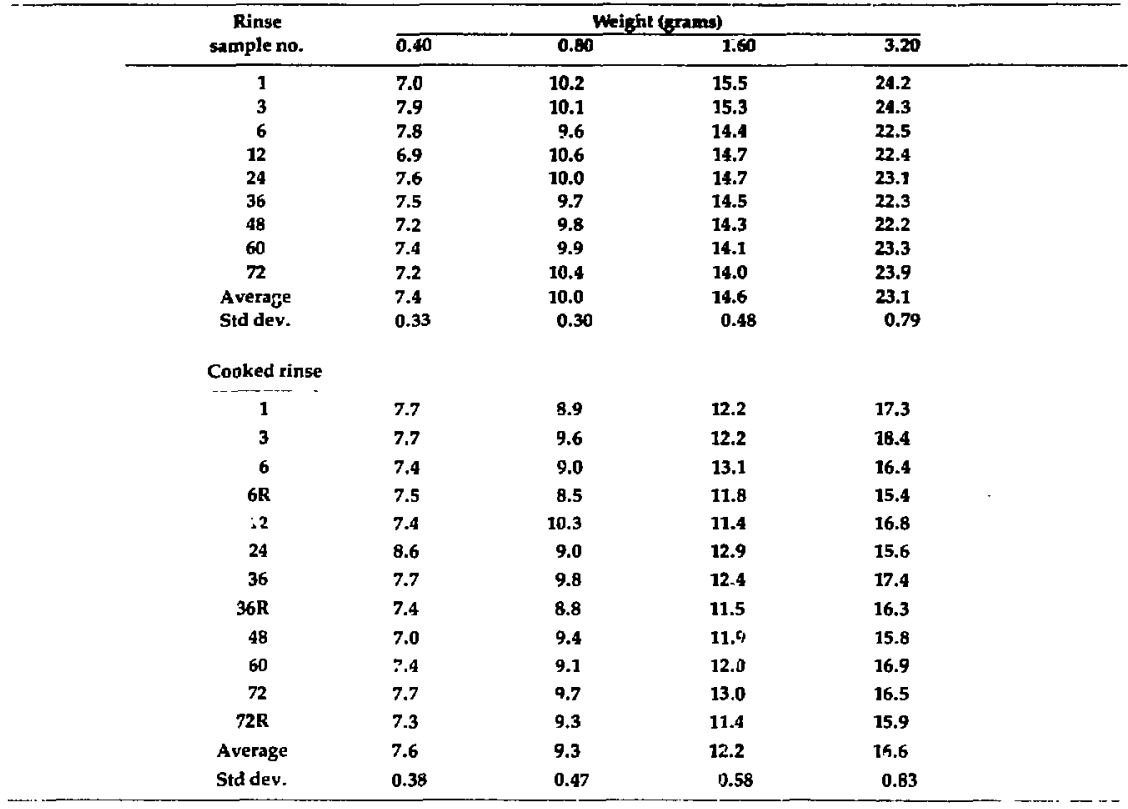


Table 13. Sodium concentration in room temperature rinse solutions and ovemight-cooked rinse solutions. J-13 $\mathrm{Nz}=43.9 \mathrm{ppm}$.

\begin{tabular}{|c|c|c|c|c|}
\hline \multirow{2}{*}{$\begin{array}{c}\text { Rinse } \\
\text { sample no. }\end{array}$} & \multicolumn{4}{|c|}{ Weight (grams) } \\
\hline & 0.40 & 0.80 & 1.60 & $3 . \overline{20}$ \\
\hline 1 & 42.2 & 43.8 & 49.8 & 59.5 \\
\hline 3 & 43.9 & 44.9 & 49.9 & 57.3 \\
\hline 6 & 44.5 & 43.0 & 47.1 & 54.7 \\
\hline 12 & 40.3 & 45.4 & 48.4 & 54.4 \\
\hline 24 & 44.1 & 42.8 & 47.9 & 56.8 \\
\hline 36 & 42.8 & 42.8 & 47.9 & 54.2 \\
\hline 48 & 41.3 & 42.6 & 45.7 & 52.9 \\
\hline 60 & 40.1 & 41.1 & 45.0 & 53.9 \\
\hline 72 & 41.2 & 44.9 & 45.9 & 57.8 \\
\hline Average & 42.3 & 43.5 & 47.5 & 55.7 \\
\hline Std dev. & 1.6 & 1.3 & 1.6 & 2.1 \\
\hline \multicolumn{5}{|c|}{ Cooked rinse } \\
\hline 1 & 46.2 & 44.8 & 48.1 & 53.2 \\
\hline 3 & 44.0 & 45.5 & 48.3 & 57.8 \\
\hline 6 & 44.0 & 44.4 & 50.8 & 53.1 \\
\hline $6 R$ & 47.3 & 49.1 & 52.5 & 58.0 \\
\hline 12 & 44.2 & 50.4 & 44.9 & 53.7 \\
\hline 24 & 52.1 & 43.4 & 51.5 & 48.6 \\
\hline 36 & 44.9 & 46.8 & $\$ 7.5$ & 54.3 \\
\hline $36 R$ & 48.8 & 48.6 & 51.8 & 59.6 \\
\hline 48 & 40.7 & 44.1 & 45.4 & 49.3 \\
\hline 60 & 40.6 & 40.9 & 45.0 & 51.8 \\
\hline 72 & 45.7 & 46.1 & 49.9 & 52.0 \\
\hline $72 R$ & 48.0 & 49.4 & 52.2 & 57.3 \\
\hline Average & 45.5 & 46.1 & 49.0 & 54.1 \\
\hline Std dev. & 3.1 & 2.7 & 2.7 & 3.3 \\
\hline
\end{tabular}

same as those obtained for split A-4 material (Oversby, 1984).

Calcium (Table 10), potassium (Table 12), and sodium (Table 13) concentrations show a linear increase with rock sample weight. Average values for the room temperature rinse solutions for these elements are plotted in Fig. 3 as a function of sample weight. Calcium is the dominant cation, with sodium and potassium being present in somewhat lesser amounts. The amounts found for split A-3 are slightly greater than those reported previously for split A-4 (Oversby, 1984); however, the differences are very small and the proportions of the three cations are essentially constant.

Data for magnesium (Table 11) show a slight decrease in concentration from the $\mathbf{J}-13$ value for the 0.4- and 0.8-g samples and a slight increase for the 1.6- and 3.2-g samples. The cooked rinse data show substantial decreases in all cases due to the retrograde solubility of $\mathrm{MgCO}_{3}$. The same trends were observed for split A-4 material (Oversby, 1984).
Charge balance calculations for the room temperature rinse solutions show that the equivalents of positive charge added to $\mathrm{J}-13$ water by the $\mathrm{K}+$ $\mathrm{Ca}+\mathrm{Na}$ components of the caliche material exactly balance the equivalents of negative charge added by the $\mathrm{Cl}+\mathrm{NO}_{3}+\mathrm{SO}_{4}$ for the $3.2-\mathrm{g}$ samples. Negative charge exceeds positive charge by $12 \%$ for the 1.6-g samples and by $31 \%$ for the 0.8 and $0.4 \mathrm{~g}$ samples. For small sample weights, the differences between measured concentrations and $\mathrm{J}-13$ values are small; therefore, a large part of the apparent lack of charge balance may be due to uncertainties in the analyses.

\section{Test Matrix Results at $120^{\circ} \mathrm{C}$}

The test matrix used four sample weights: 0.4 , $0.8,1.6$, and $3.2 \mathrm{~g}$ of crushed Topopah Spring tuff. The volume of $J-13$ water used was $48 \mathrm{ml}$ in all cases. Blanks, which consisted of J-13 water without tuff, were nun for $3,12,24,36$, and 60 days. 
The large Parr bombs are too heavy for use with a roller device in the oven, so the tests were run in a static mode with the bombs placed upright. To prevent the rock fowder from caking on the bottom of the Teflon capsule, each bomb was shaken by hand several times a day on Monday, Wednesday, and Friday during the reaction in.erval.

Tables 14 through 17 give data for anions measured by ion chromatography. Fluoride concentrations (Table 14) show a slight increase as a function of reaction time that is not correlated with sample weight. The blank solutions also show a similar in- crease in fluoride. All fluoride concentration increases are attributed to fluoride release by the Teflon, which is a fluoro-carbon material. Chloride concentrations (Table 15) are similar to or slightly higher than J-13 chloride concentrations. Nitrate concentrations (Table 16) show behavior similar to chloride, while sulfate (Table 17 ) remains essentially at J-13 levels. These data show that there is little or no change in anion concentrations in the water as a result of reaction with the rock at $120 \mathrm{C}$. This is the same result as that obtained at 90 and $150^{\circ} \mathrm{C}$ (Oversby, 1984).

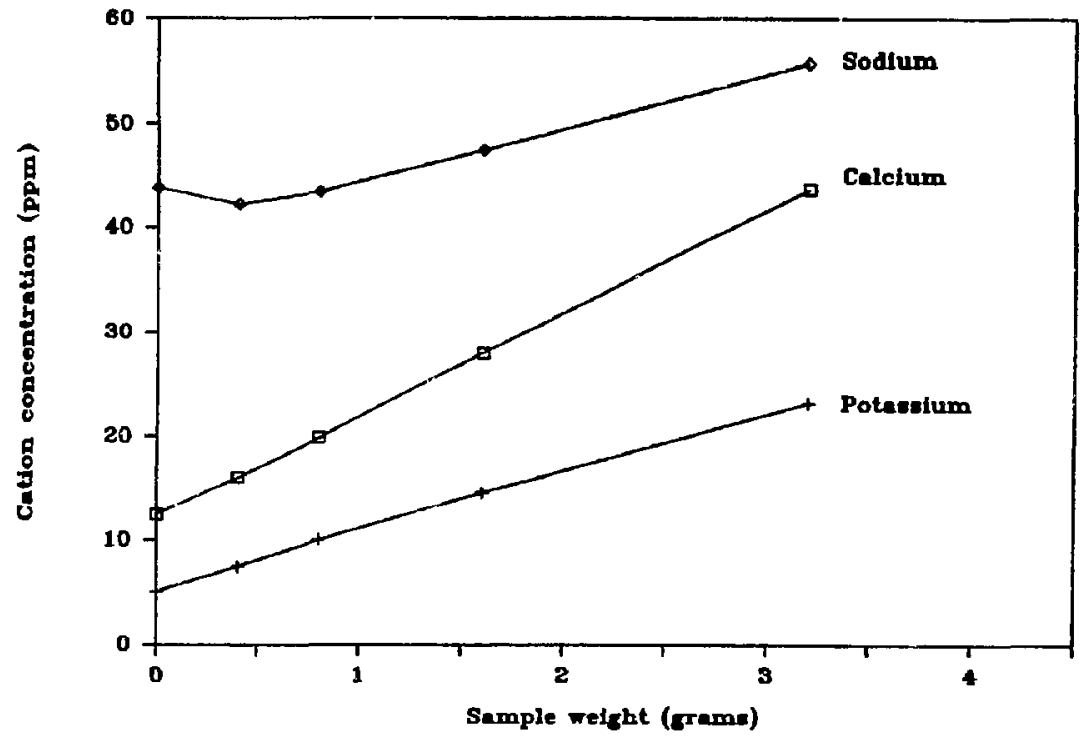

Figure 3. Concentrations of cations in pretreatment room temperature rinse solutions (Tables 10, 12, and 13) plotted as a function of sample weight.

Table 14. Fluoride concentration in ppm from reaction of Topopah Spring tuff witl $\mathrm{J}-13$ water at $120^{\circ} \mathrm{C}$. Initial J-13 fluoride concentration is $2.2 \mathrm{ppm}$.

\begin{tabular}{|c|c|c|c|c|c|}
\hline \multirow{2}{*}{$\begin{array}{l}\text { Run time } \\
\text { (days) }\end{array}$} & \multicolumn{4}{|c|}{ Sample weight (grams) } & \multirow[b]{2}{*}{ Blank } \\
\hline & 0.1 & 0.8 & 1.6 & 3.2 & \\
\hline 1 & 2.2 & 2.1 & 2.1 & 2.1 & \\
\hline 3 & 2.2 & 2.3 & 2.2 & 2.4 & 2.2 \\
\hline 6 & 2.2 & 2.1 & 2.1 & 2.5 & \\
\hline 12 & 2.3 & 2.3 & 2.3 & 2.4 & 2.2 \\
\hline 24 & 2.4 & 2.4 & 2.2 & 2.3 & 2.3 \\
\hline 36 & 3.6 & 2,4 & 2.5 & 2.6 & 2.7 \\
\hline 48 & 2.4 & 2.5 & 2.5 & 2.5 & \\
\hline 60 & 2.7 & 2.8 & 2.5 & 2.6 & 2.5 \\
\hline 72 & 2.5 & 2.8 & 2.8 & 2.6 & \\
\hline
\end{tabular}


Table 15. Chloride concentration in ppm from reaction of Topopah Spring tuff with J-13 water at $120^{\circ} \mathrm{C}$. Initial ]-13 chloride concentration is $6.9 \mathrm{ppm}$.

\begin{tabular}{|c|c|c|c|c|c|}
\hline \multirow{2}{*}{$\begin{array}{c}\text { Run time } \\
\text { (dayel) }\end{array}$} & \multicolumn{4}{|c|}{ Sample weight (grams) } & \multirow[b]{2}{*}{ Blank } \\
\hline & $\overline{0.4}$ & 0.8 & 1.6 & 3.2 & \\
\hline 1 & 8.0 & 7,6 & 7.7 & 7.8 & \\
\hline 3 & 7.0 & 7.0 & 7.1 & 7.4 & 7.0 \\
\hline 6 & 7.5 & 7.6 & 6.7 & 7.6 & \\
\hline 12 & 7.0 & 7.2 & 7.4 & 7.7 & 7.1 \\
\hline 29 & 7.4 & 7.4 & 7.3 & 8.1 & 7.1 \\
\hline 36 & 8.5 & 7.1 & 7.5 & 7.9 & 7.3 \\
\hline 49 & 6.9 & 7.1 & 7.3 & 7.9 & \\
\hline 60 & 7.2 & 7.2 & 7.3 & 8.0 & 6.9 \\
\hline 72 & 7.2 & 7.3 & 7.6 & 8.0 & \\
\hline
\end{tabular}

Table 16. Nitrate concentration in Fpm from reaction of Topopych Spring tuff with J-13 water at $120^{\circ} \mathrm{C}$. Initial J-13 nitrate concentration is 9.5 ppm.

\begin{tabular}{|c|c|c|c|c|c|}
\hline \multirow{2}{*}{$\begin{array}{l}\text { Run time } \\
\text { (days) }\end{array}$} & \multicolumn{4}{|c|}{ Sample weight (grams) } & \multirow[b]{2}{*}{ Blank } \\
\hline & $\overline{0.4}$ & 0.8 & 1.6 & $\overline{3.2}$ & \\
\hline 1 & 8.7 & 9.1 & 8.5 & 8.9 & \\
\hline 3 & 9.1 & 9.2 & 8.8 & $\mathbf{1 0 . 4}$ & 9.3 \\
\hline 6 & 9.4 & 9.1 & 9.0 & 10.8 & \\
\hline 12 & 9,0 & 9.5 & 10.3 & 11.7 & 9.1 \\
\hline 24 & 9.6 & 9.2 & 10.0 & 12.1 & 9.1 \\
\hline 36 & 9.9 & 10.2 & 10.8 & 12.7 & 9.8 \\
\hline 48 & 9.3 & 9.5 & 10.2 & 11.0 & \\
\hline 60 & 9.6 & 9.9 & 9.5 & 13.2 & 9.4 \\
\hline 72 & 9.9 & 10.0 & 10.2 & 12.4 & \\
\hline
\end{tabular}

Table 17. Sulfate concentration in ppm from reaction of Topopah Spring tuff with J-13 water at $120^{\circ} \mathrm{C}$. Initial J-13 sulfate concentration is $18.7 \mathrm{ppm}$.

\begin{tabular}{|c|c|c|c|c|c|}
\hline \multirow{2}{*}{$\begin{array}{l}\text { Run time } \\
\text { (days) }\end{array}$} & \multicolumn{4}{|c|}{ Sample weight (grams) } & \multirow[b]{2}{*}{ Blank } \\
\hline & $\overline{0.4}$ & 0.8 & 1.6 & 3.2 & \\
\hline 1 & 19.1 & 19.3 & 20.4 & 19.3 & \\
\hline 3 & 17.9 & 28.1 & 18.6 & 18.4 & 17.8 \\
\hline 6 & 19.8 & 19.0 & 17.1 & 19.7 & \\
\hline 12 & $\mathbf{1 8 . 0}$ & 17.9 & 18.1 & 19.2 & 18.2 \\
\hline 24 & 17.8 & 14.4 & 17.9 & 19.2 & 17.8 \\
\hline 36 & 17.8 & 18.2 & 18.7 & 19.7 & 19.5 \\
\hline 48 & 17.8 & 18.1 & 18.1 & 19.1 & \\
\hline 60 & 18.2 & 18.0 & 17.9 & 19.3 & 18.1 \\
\hline 72 & 18.4 & 18.2 & 19.1 & 18.7 & \\
\hline
\end{tabular}

Table 18a gives alkalinity of solutions in meq/l and Table $18 \mathrm{~b}$ gives alkalinity calculated as ppm $\mathrm{HCO}_{3}^{-}$. Alkalinity decreases in the blank solutions due to precipitation of magnesium and calcium carbonates. In addition, some carbon dioxide is probably lost to the Teflon capsule, with a resultant decrease in alkalinity (Knauss et al., 1983). Data for calcium, magnesium, and alkalinity for the blank solutions indicate that for all cases except the 3-day blank, the alkalinity is lowar than can be explained by precipitation of $(\mathrm{Ca}, \mathrm{Mg}) \mathrm{CO}_{3}$ alone. This supports the suggestion that some $\mathrm{CO}_{2}$ is lost to the Teflon. Table 19 lists the $\mathrm{pH}$ values for solutions at the end of the reaction period. Most of the increase in $\mathrm{pH}$ is attributed to the loss of $\mathrm{CO}_{2}$ to the Teflon; reactions in gold-bag rocking autoclaves do not show an increase in $\mathrm{pH}$ (Knauss et al., 1983).

Aluminum concentrations (Table 20) increase fairly rapidly and then show a slight decrease for 
Table 18. Alkalinity measured from reaction of Topopah Spring tuff with J-13 water at $120 \%$ C.

a. Alkalinity in meq/l. Initial J-13 alkalinity is $2.23 \mathrm{meq} / \mathrm{l}$.

\begin{tabular}{|c|c|c|c|c|c|}
\hline \multirow{2}{*}{$\begin{array}{l}\text { Run time } \\
\text { (days) }\end{array}$} & \multicolumn{4}{|c|}{ Sample weight (grams) } & \multirow[b]{2}{*}{ Dlank } \\
\hline & $\overline{0.4}$ & 0.8 & 1.6 & $\overline{3.2}$ & \\
\hline 1 & 1.81 & 1.84 & 1.99 & 1.59 & \\
\hline 3 & 1.86 & 1.87 & 2.00 & 1.78 & 2.02 \\
\hline 6 & 1.77 & 1.86 & 1.86 & 1.91 & \\
\hline 12 & 1.70 & 1.79 & 1.76 & 1.86 & 1.58 \\
\hline 24 & 1.60 & 1.72 & 1.70 & 1.90 & 1.42 \\
\hline 36 & 1.75 & 1.73 & 1.74 & 1.81 & 1.55 \\
\hline 48 & 1.66 & 1.72 & 1.77 & 1.76 & \\
\hline 60 & 1.78 & 1.72 & 1.50 & 1.85 & 1.37 \\
\hline 72 & 1.72 & 1.71 & 1.78 & 1.84 & \\
\hline
\end{tabular}

b. Alkalinity in ppm bicarbonate. Initial J-13 alkalinity is $136 \mathrm{ppm}$ bicarbonate.

\begin{tabular}{|c|c|c|c|c|c|}
\hline \multirow{2}{*}{$\begin{array}{l}\text { Run tisne } \\
\text { (days) }\end{array}$} & \multicolumn{4}{|c|}{ Sample weight (grams) } & \multirow[b]{2}{*}{ Blank } \\
\hline & $\overline{0.4}$ & 0.8 & 1.6 & 3.2 & \\
\hline 1 & 110 & 112 & 121 & 121 & \\
\hline 3 & 113 & 114 & 122 & 109 & 123 \\
\hline 6 & 108 & 113 & 113 & 157 & \\
\hline 12 & 104 & 109 & 107 & $\mathbf{1 1 . 3}$ & 96 \\
\hline 24 & 103 & 105 & 104 & 116 & 87 \\
\hline 36 & 107 & 106 & 106 & 110 & 95 \\
\hline 48 & T01 & 105 & 108 & 107 & \\
\hline 60 & 109 & 105 & 110 & 113 & 84 \\
\hline 72 & 105 & 104 & 109 & 112 & \\
\hline
\end{tabular}

Table 19. $\mathrm{pH}$ of solutions from reaction of Topopah Spring tuff with J-13 water at $120^{\circ} \mathrm{C}$. Initial $\mathrm{J}-13 \mathrm{pH}=7.6$.

\begin{tabular}{|c|c|c|c|c|c|}
\hline \multirow{2}{*}{$\begin{array}{l}\text { Reaction time } \\
\text { (days) }\end{array}$} & \multicolumn{4}{|c|}{ Weight (grams) } & \multirow[b]{2}{*}{ Blank } \\
\hline & $\overline{0} . \overline{4}$ & $\overline{0.8}$ & $1 . \overline{6}$ & $\overline{3.2}$ & \\
\hline 1 & 8.15 & 8.10 & 8.21 & 8.32 & \\
\hline 3 & 7.93 & 8.02 & 8.16 & 8.24 & 7.96 \\
\hline 6 & 8.02 & 8.02 & 8.20 & 8.29 & \\
\hline 12 & 7.88 & 8.03 & 8.05 & 8.15 & \\
\hline 24 & 8.14 & 8,38 & 8.35 & 8.41 & $\mathbf{8 . 3 0}$ \\
\hline 36 & 8.38 & 8.59 & 8.57 & 8.56 & 8.44 \\
\hline 48 & 8.34 & 8.43 & 8.80 & 8.78 & \\
\hline 60 & 8.13 & 8.43 & 8.42 & 8.72 & 8.59 \\
\hline 72 & 8.94 & 8.86 & 8.84 & 8.99 & \\
\hline
\end{tabular}

Table 20. Concentration of aluminum in soLutions from reaction of Topopah Spring tuff with J-13 water at $120^{\circ} \mathrm{C}$. Initial J-13 $\mathrm{Al}=0.012 \mathrm{ppm}$.

\begin{tabular}{|c|c|c|c|c|c|c|}
\hline \multirow{2}{*}{$\begin{array}{l}\text { Reaction time } \\
\text { (days) }\end{array}$} & & \multicolumn{4}{|c|}{ Weight (grams) } & \multirow[b]{2}{*}{ Blank } \\
\hline & & 0.4 & 0.8 & 1.6 & 3.2 & \\
\hline 1 & & 1.29 & 1.90 & 1.85 & 1.52 & \\
\hline 3 & & 1.62 & 2.05 & 1.96 & 1.43 & 0.011 \\
\hline 6 & & 1.91 & 2.13 & 1.84 & 1.34 & \\
\hline 6 & , & 1.84 & 1.98 & 1.78 & 1.31 & Rerun ICP 6/22/84 \\
\hline 12 & , & 1.74 & 1.96 & 1.69 & 1.24 & 0.019 \\
\hline 24 & & 1.78 & 2.10 & 1.69 & 1.17 & 0.016 \\
\hline 36 & & 1.77 & 2.12 & 1.73 & 1.17 & 0.015 \\
\hline 48 & & 1.68 & 1.95 & 1.68 & 1.18 & \\
\hline 60 & & 1.58 & 1.78 & 1.38 & 1.09 & 0.015 \\
\hline 72 & & 1.65 & 1.99 & 1.56 & 1.21 & \\
\hline
\end{tabular}


longer reaction times. The slow decrease is most clearly seen in the data for the $1.6-$ and $3.2-\mathrm{g} \mathrm{sam}$ ples (Fig. 4). The line labelled "Rerun ICP 6/22/ 84 " represents a reanalysis of the same solution that was originally analyzed on 8/4/83. Agreement, of the results for aluminum for analyses made more than 10 months apart indicates that solution concentrations for aluminum are remarkably stable at room temperature for these samples. The behavior of aituminum at $120^{\circ} \mathrm{C}$ is intermediate between that seen at 90 and $150^{\circ} \mathrm{C}$ (Oversby, 1984).

Table 21 gives the boron concentrations for the solutions. Data for the 6-day samples were run on $8 / 4 / 83$, at which time there was a problem with boron data reduction (see the "Experimental Procedures" section for details). Because boron should not precipitate from the solution, even during long term storage of the solutions, the samples were reanalyzed after the difficulties with boron data treatment were corrected. The line labelled "Rerun ICP 6/22/84" is the reanalysis of the same solution. The boron levels found on 6/22/84 are consistent with the pattern established by the other results and lend credence to our assumption that boron should not precipitate from solution during storage at room temperature. There is a slight correlation of boron content with sample weight and reaction time at a given sample weight. The differences are small, especially as a function of reaction time, and may relate to incomplete removal of the soiuble boron component rather than reaction of the major rock phases with the water.

Data for iron (Table 22) show that there is very little increase in iron in solution as a result of reaction of $\mathrm{J}-13$ water with the tuff at $120^{\circ} \mathrm{C}$. This is partly because of the limited amount of iron present in the rock, but it is mainly the result of the oxidizing conditions in the reaction system and the low solubility of iron under those conditions.

Data for silicon (Table 23) show an initial sharp increase followed by a further slow increase, as shown in Fig. 5, where the data for each sample weight are plotted as a function of reaction time. Data for the sample run after more than $\mathbf{1 0}$ months of storage at room temperature again show remarkabie stability of solution concentrations over long storage periods. The same data are plotted in

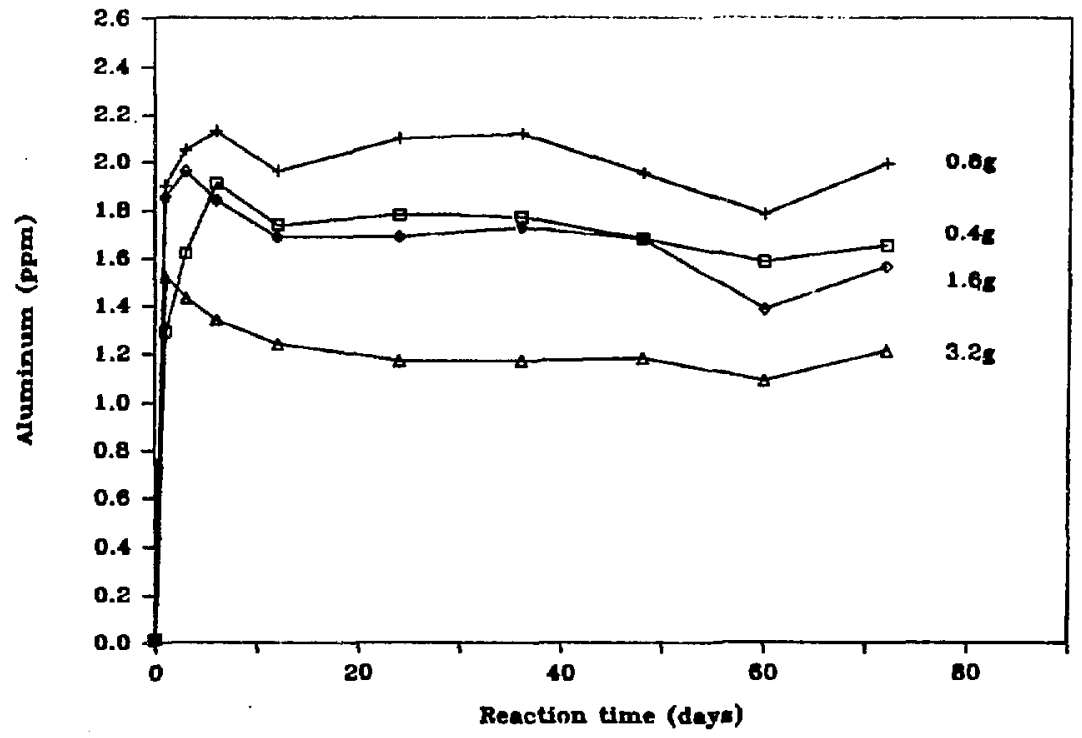

Figure 4. Aluminum solution concentrations plotted as a function of reaction time. 
Table 21. Concentration of boron in solutions from reaction of Topopah 5 pring tuff with $7-13$ water at $120^{\circ} \mathrm{C}$. Initial $\mathrm{J}-13 \mathrm{~B}=0.13 \mathrm{ppm}$.

\begin{tabular}{|c|c|c|c|c|c|}
\hline \multirow{2}{*}{$\begin{array}{l}\text { Reaction time } \\
\text { (days) }\end{array}$} & \multicolumn{4}{|c|}{ Weight (grams) } & \multirow[b]{2}{*}{ Dlank } \\
\hline & $\overline{0.4}$ & 0.8 & 1.6 & 3.2 & \\
\hline 1 & 0.116 & 0.116 & 0.117 & 0.119 & \\
\hline 3 & 0.132 & 0.134 & 0.138 & 0.153 & 0.133 \\
\hline 6 & 0.027 & 0.026 & 0.029 & 0.040 & \\
\hline 6 & 0.140 & 0.137 & 0.145 & 0.155 & Rerun ICP 6/22 : ; \\
\hline 12 & 0.130 & 0.129 & 0.137 & 0.157 & 0.126 \\
\hline 24 & 0.133 & i. 139 & 0.138 & 0.155 & 0.118 \\
\hline 36 & 0.127 & 0.123 & 0.133 & 0.156 & 0.119 \\
\hline 48 & 0.231 & 0.137 & 0.144 & 0.166 & \\
\hline 60 & 0.137 & 0.134 & 0.145 & 0.173 & 0.118 \\
\hline 72 & 0.140 & 0.144 & 0.152 & 0.179 & \\
\hline
\end{tabular}

Tabie 22. Concentration of iron in solutions from reaction of Topopah Spring tuff svith J-13 water at $120^{\circ} \mathrm{C}$. Initial $\mathrm{J}-13 \mathrm{Fe}=0.006 \mathrm{ppm}$.

\begin{tabular}{|c|c|c|c|c|c|}
\hline \multirow{2}{*}{$\begin{array}{c}\text { Reaction time } \\
\text { (days) }\end{array}$} & \multicolumn{4}{|c|}{ Weight (grams) } & \multirow[b]{2}{*}{ Blank } \\
\hline & $\overline{0.4}$ & 0.8 & 1.6 & 3.2 & \\
\hline 1 & 0.024 & 0.052 & 0.056 & 0.046 & \\
\hline 6 & 0.007 & 0.006 & 0.007 & 0.005 & \\
\hline 6 & 0.029 & 0.016 & 0.022 & 0.015 & Rerun ICP 6:22;84 \\
\hline 12 & 0.012 & 0.038 & 0.023 & 0.029 & 0.040 \\
\hline 48 & 0.053 & 0.016 & 0.028 & 0.013 & \\
\hline 60 & 0.024 & 0.049 & 0.024 & 0.022 & 0.463 \\
\hline 72 & 0.031 & 0.044 & 0.028 & 0.035 & \\
\hline
\end{tabular}

Table 23. Concentration of silicon in solutions from reaction of Topopah Spring tuff with J-13 water at $120^{\circ} \mathrm{C}$. Initial J-13 $\mathrm{Si}=27.0 \mathrm{ppm}$.

\begin{tabular}{|c|c|c|c|c|c|}
\hline \multirow{2}{*}{$\begin{array}{l}\text { Reaction time } \\
\text { (days) }\end{array}$} & \multicolumn{4}{|c|}{ Weight (grams! } & \multirow[b]{2}{*}{ Blank } \\
\hline & 0.4 & 0.8 & 1.6 & 3.2 & \\
\hline 1 & 33.4 & 34.8 & 37.9 & 40.4 & \\
\hline 6 & 39.9 & 41.2 & 44.5 & 50.3 & \\
\hline 6 & 40.1 & 41.5 & 44.9 & 51.5 & Merun ICP 6/22/84 \\
\hline 12 & 44.9 & 45.1 & 49.3 & 57.3 & 24.8 \\
\hline 48 & 51.7 & 52.7 & 59.8 & 70.5 & \\
\hline 60 & 50.8 & 52.3 & 57.5 & 73.6 & 24.6 \\
\hline 72 & 56.5 & 55.5 & 62.8 & 76.5 & 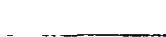 \\
\hline
\end{tabular}




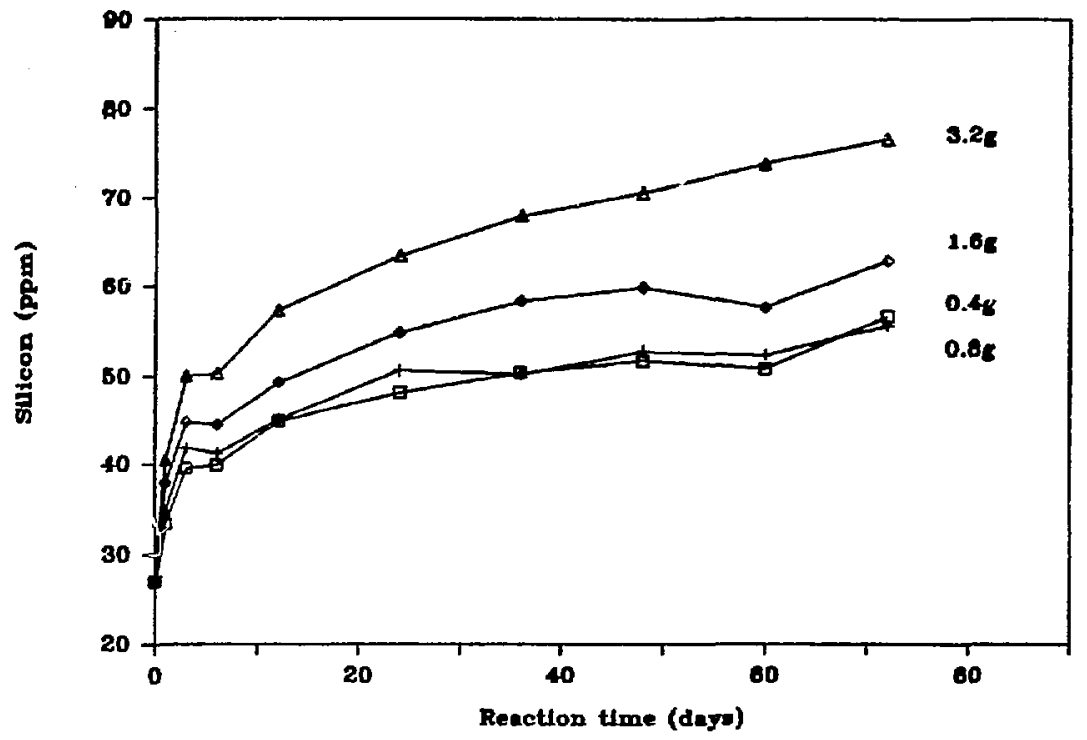

Figure 5. Silicon solution concentrations plotted as a function of reaction time.

Fjg. 6 as a function of a "normalized reaction parameter." Data for the 3.2-g sample are plotted in Fig. 6 vs the duration of the reaction (in days). Data for the 1.6-g sample are plotted vs the reaction time divided by two; this adjusts for the difference in the ratio of sample surface area to solution volume for the two samples. The normalized reaction parameter is calculated by multiplying the ratio (sample $w t / 3.2$ ) times reaction time. If the reaction rate were dependent on the ratio of sample surface area to sulution volume (SA/V), the data would define a single curve in the normalized reaction parar eter plot. While there is some scatter in the sis in Fig. 6, the dependence of reaction tate on SA/V is clear.

Data for $120^{\circ} \mathrm{C}$ silicon concentrations for the largest ratio of sample weight to solution volume are plotted in Fig. 7 along with data for reaction at 90 and $150^{\circ} \mathrm{C}$ for the same weight-to-volume ratio. As would be expected, the data at $120^{\circ} \mathrm{C}$ are intermediate between the results for the other two temperatures, and are somewhat closer to the $150^{\circ} \mathrm{C}$ values.
Results for calcium (Table 24) and magnesium (Table 25) show similar behavior, with an initial sharp decrease in concentration followed by a slow further decrease. After 72 days of reaction the concentration of calcium is approximat $P ! y$ 3.5 ppm whereas the concentration of magnesium is about $0.1 \mathrm{ppm}$. These concentrations are both higher than those found at $150^{\circ} \mathrm{C}$ and lower than those found at $90^{\circ} \mathrm{C}$, a fact that is consistent with the retrograde solubility of mag, nesium and calcium carbonate (Oversby, 1984). The data for the sample rerun after long storage show $>$ slight decrease in solution concentrations of calcium; the ieason for this is not known.

Potassium (Table 26) and sodium (Table 27) show no clear trend as a function of reaction time, but do show a slight positive correlation with sample weight. The correlation is more regular in the case of potassium than sodium. This may either be caused by the dissolution of some residual soluble material or by the rapid dissolution of a small amount of feldspar. The correlation with sample weight favors the former explanation. Potassium 


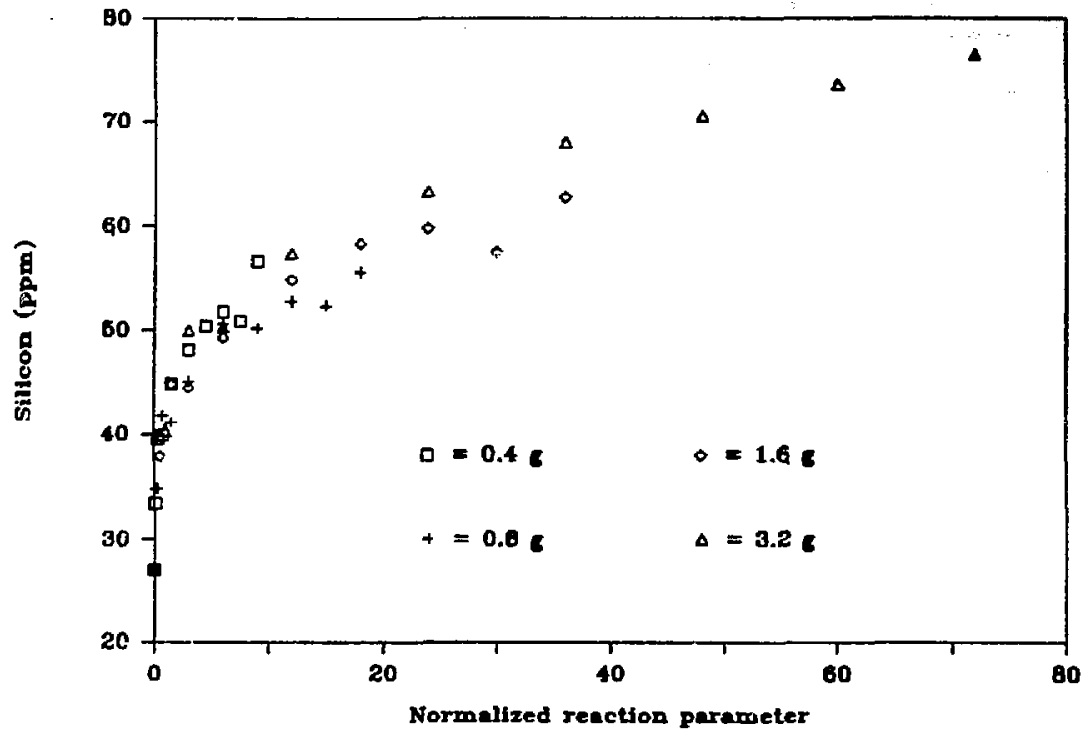

Figure 6. Silicon concentrations plotted as a function of a normalized reaction parameter. See fext for details.

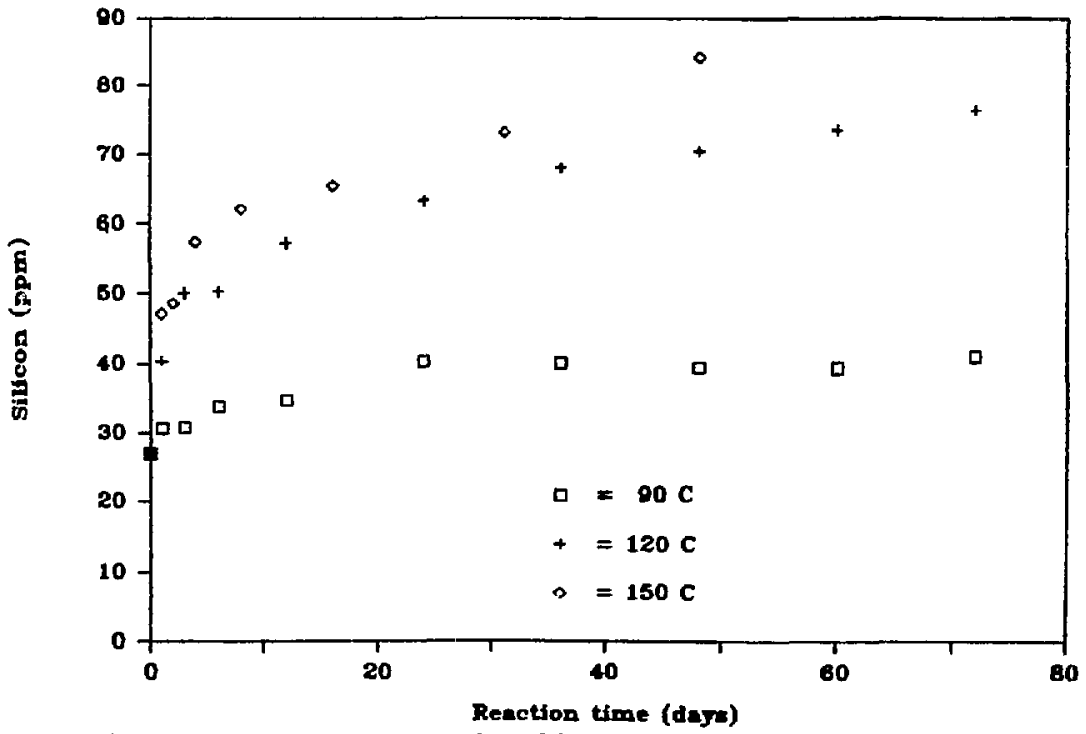

Figure 7. Silicon concentration at 90,120 , and $150^{\circ} \mathrm{C}$ for constant sample weight to solution volume plotted as a function of reaction time. 
concentrations are similar to those reported previously for 90 and $150^{\circ} \mathrm{C}$, whereas sodium concentrations are somewhat higher (Oversby, 1984). Potassium data for the rerun samples with $0.4,1.6$, and $3.2 \mathrm{~g}$ of rock were run in a sample set that gave a low value of potassium in the $\mathrm{J}-13$ control blank (No. 6, Table 1C). There is probably no significant change in potassium in solution as a function of storage time. The $0.8-\mathrm{g}$ rerun was run with a set of samples for which the control blank gave correct values for potassium and shows no significant difference from the first aralysis. Sodium data for the rerun sample are within error limits of the first analysis.

Table 24. Concentration of calcium in solutions from reaction of Topopah Spring tuff with J-13 water at $120^{\circ} \mathrm{C}$. Initial j-13 $\mathrm{Ca}=12.5 \mathrm{ppm}$.

\begin{tabular}{|c|c|c|c|c|c|}
\hline \multirow{2}{*}{$\begin{array}{l}\text { Reaction time } \\
\text { (days) }\end{array}$} & \multicolumn{4}{|c|}{ Weight (grams) } & \multirow[b]{2}{*}{ Blank } \\
\hline & 0.4 & 0.8 & 1.6 & 3.2 & \\
\hline 1 & 6.71 & 7.08 & 8.84 & 9.41 & \\
\hline 3 & 7.63 & 7.95 & 9.26 & 10.30 & 5.21 \\
\hline 6 & 6.30 & 7.04 & 6.86 & 7.31 & \\
\hline 6 & 5.97 & 6.42 & 6.50 & 7.00 & Rerun ICP 6/22/84 \\
\hline 12 & 6.22 & 5.86 & 6.76 & 7.03 & 3.76 \\
\hline 24 & 5.29 & 4.95 & 4.59 & 4.96 & 2.43 \\
\hline 36 & 4.17 & 3.75 & 3.97 & 4.19 & 2.05 \\
\hline 48 & 4.62 & 4.95 & 3.94 & 4.11 & \\
\hline 60 & 4.88 & 4.47 & 4.48 & 4.34 & 2.26 \\
\hline 72 & 3.44 & 3.63 & 3.74 & 3.59 & \\
\hline
\end{tabular}

Table 25. Concentration of magnesium in solutions from reaction of Topopah Spring tuff with J-13 water at $120^{\circ} \mathrm{C}$. Initial J-13 $\mathrm{Mg}=1.92 \mathrm{ppm}$.

\begin{tabular}{|c|c|c|c|c|c|}
\hline \multirow{2}{*}{$\begin{array}{l}\text { Reaction time } \\
\text { (days) }\end{array}$} & \multicolumn{4}{|c|}{ Weight (grams) } & \multirow[b]{2}{*}{ Blank } \\
\hline & $\overline{0.4}$ & 0.8 & 1.6 & 3.2 & \\
\hline 1 & 0.235 & 0.265 & 0.273 & 0.219 & \\
\hline 3 & 0.272 & 0.213 & 0.231 & 0.235 & 0.596 \\
\hline 6 & 0.102 & 0.095 & 0.000 & 0.071 & \\
\hline 6 & 0.126 & 0.093 & 0.088 & 0.070 & Rerun ICP 6/22/84 \\
\hline 12 & 0.099 & 0.153 & 0.111 & 0.117 & 0.289 \\
\hline 24 & 0.173 & 0.116 & 0.119 & 0.180 & 0.176 \\
\hline 36 & 0.152 & 0.058 & 0.262 & 0.134 & 0.124 \\
\hline 48 & 0.197 & 0.076 & 0.082 & 0.051 & \\
\hline 60 & 0.115 & 0.181 & 0.097 & 0.079 & 0.180 \\
\hline 72 & 0.096 & 0.138 & 0.095 & 0.109 & \\
\hline
\end{tabular}

Table 26. Concentration of potassium in solutions from reaction of Topopah Spring tuff with J-13 water at $120^{\circ} \mathrm{C}$. Initial J-13 K = 5.1 Ppm.

\begin{tabular}{|c|c|c|c|c|c|}
\hline \multirow{2}{*}{$\begin{array}{c}\text { Reaction time } \\
\text { (days) }\end{array}$} & \multicolumn{4}{|c|}{ Weight (grams) } & \multirow[b]{2}{*}{ Blank } \\
\hline & $\overline{0.4}$ & 0.8 & 1.6 & 3.2 & \\
\hline 1 & 5.6 & 6.4 & 7.6 & 9.3 & \\
\hline 3 & 6.2 & 6.8 & 8.9 & 10.9 & 5.0 \\
\hline 6 & 6.9 & 7.2 & 8.4 & 10.8 & \\
\hline 6 & 6.1 & 5.9 & 7.8 & 9.5 & Rerun ICP 6/22/84 \\
\hline 12 & 6.3 & 6.8 & 8.2 & 10.4 & 4.5 \\
\hline 24 & 6.6 & 7.1 & 8.1 & 9.5 & 4.5 \\
\hline 36 & 6.0 & 6.9 & 7.5 & 8.8 & 4.3 \\
\hline 48. & 6.3 & 7.3 & 7.8 & 8.9 & 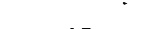 \\
\hline 60 & 6.0 & 7.1 & 7.9 & 9.9 & 4.7 \\
\hline $\mathbf{7}$ & 6.0 & 7.1 & 8.2 & 9.2 & \\
\hline
\end{tabular}


Table 27. Concentration of sodium in solutions from reaction of Tbpepah Spring triff with J-13 water at $120^{\circ} \mathrm{C}$. Initial J-13 Na $=44 \mathrm{ppm}$.

\begin{tabular}{|c|c|c|c|c|c|}
\hline \multirow{2}{*}{$\begin{array}{l}\text { Reaction time: } \\
\text { (days) }\end{array}$} & \multicolumn{4}{|c|}{ Weighl (grams) } & \multirow[b]{2}{*}{ Dtank } \\
\hline & $\overline{0.4}$ & 0.8 & 1.6 & 3.2 & \\
\hline 1 & 41.0 & 40.3 & 43.4 & 424 & \\
\hline 3 & 45.9 & 46.2 & 51.3 & 52.3 & 46.2 \\
\hline 6 & 43.3 & 44.7 & 44.5 & 46.2 & \\
\hline 6 & 44.4 & 43.7 & 45.0 & 47.1 & Rerven ICP GI22/84 \\
\hline 12 & 43.0 & 42.2 & 45.2 & 47.1 & 4.6 \\
\hline 24 & 46.5 & 46.8 & 45.3 & 45.4 & 40.7 \\
\hline 36 & 44.7 & 43.1 & 44.0 & 45.1 & 39.5 \\
\hline 48 & 45.4 & 46.1 & 45.6 & 47.3 & \\
\hline 60 & 42.7 & 44.1 & 44.6 & 51.1 & 40.9 \\
\hline 72 & 46.5 & 44.7 & 47.0 & 50.4 & \\
\hline
\end{tabular}

Table 28. Estimate of steady-state water chemistry for the system Topopah Spring Tuff - J-13 water.

\begin{tabular}{lccc} 
& & Concentration (ppm) & \\
\cline { 2 - 3 } Element & $90^{\circ} \mathrm{C}$ & $120^{\circ} \mathrm{C}$ & $150^{\circ} \mathrm{C}$ \\
\hline $\mathrm{Al}$ & 0.4 & 1.2 & 1 \\
$\mathrm{~B}$ & 0.1 & 0.1 & 0.1 \\
$\mathrm{Fe}$ & 0 & 0 & 0 \\
$\mathrm{Si}$ & 49 & 81 & 122 \\
$\mathrm{Ca}$ & 8 & 3.5 & 3 \\
$\mathrm{Mg}$ & 0.2 & 0.1 & 0.1 \\
$\mathrm{~K}$ & 9 & 9 & 9 \\
$\mathrm{Na}$ & 40 & 45 & 40 \\
$\mathrm{~F}$ & 2 & 2 & 2 \\
$\mathrm{Cl}$ & 7 & 7 & 7 \\
$\mathrm{NO}_{3}$ & 9 & 9 & 9 \\
$\mathrm{SO}_{4}$ & 18 & 18 & 18 \\
2 From Oversby (1984). & & &
\end{tabular}

\section{Estimation of Steady-State Water Chemistry}

None of the experiments reported in this paper reached steady-state solution concentrations. The matrix permeability of the Topopah Spring tuff is low and the downward infiltration rate of water at Yucca Mountain is also low. This suggests that water flow through the rock matrix material at the repository level would be slow enough to achieve steady-state solution compositions at the appropriate temperatures. Long term experiments using J-13 water and Topopah Spring tuff are in progress in Teflon reaction vessels and in gold-bag rocking autoclaves to determine the steady-state chemistry. Pending completion of those experiments, the data given above will be used together with the solubility of cristobalite to predict the steady-state solution compositions.

Table 28 gives the estimated water chemistry at steady state for the system Topopah Spring tuff plus J-13 water. Data given in the sections on results showed that the only source of anions to change the water chemistry came from the caliche component, and not from the rock itself. Experiments using rock from drill cores have established that there is no caliche material associated with the Topopah Spring tuff $\mathrm{f}$ were it lies below the region affected by surface runoff (Oversby, 1983). Thus, the estimates for anions are simply the original J-13 values, with a slight lowering in the case of sulfate to allow for some precipitation. Estimates for the expected composition at 90 and $150^{\circ} \mathrm{C}$ are from Oversby (1984). 
Boron and iron concentrations are not expected to change significantly as the result of hydrothermal reaction of the Topopah Spring tuff and $\mathrm{J}-13$ water. Potassium and sodium increase slightly, and appear to be essentially independent of temperature. Aluminum concentrations will increase above $\mathrm{J}-13$ values, and presently exhibit a maximum value for the $120^{\circ} \mathrm{C}$ data set. Calcium and magnesium concentrations will decrease. Sili- con concentrations have been set at the cristobalite solubility level (calculated from data in Walther and Helgeson, 197\%) for each temperature. Quartz is present in the rock and may control silicon solubility in the very long term; however, data obtained to date indicate that silica precipitation is very slow, and the kinetics of quartz formation may be too slow to control the solubility.

\section{Conclusions}

Reaction of the Topopah Spring Member of the Paintbrush Tuff with J-13 well water, a groundwater obtained from a locality at which the Topopah Spring tuff is an aquifer, shows that changes in water chemistry due to heating the rock and water at $120^{\circ} \mathrm{C}$ are limited to minor effects in all cases except silicon. Silicon concentrations increase as a result of dissolution of cristobalite and are expectec to reach $81 \mathrm{ppm}$ at $120^{\circ} \mathrm{C}$ at steady-state.

The surface outcrop samples used in these experiments contained a substantial amount of easily removed evaporite deposits on the rock surface. This type of material is not expected to be encountered at depth under Yucca Mountain (Oversby, 1983) and should be removed before the rock is used in experiments where the evaporite material might affect the results. A relatively simple pretreatment procedure is effective in removing the evaporite salts.

Anion data show that there is no detectable source of anions in the rock at $120^{\circ} \mathrm{C}$.

The $\mathrm{pH}$ of these experiments increased as a result of reaction. Data from comparable experiments conducted in gold-bag rocking autoclaves do not show such an increase (Knauss et al., 1983). The increase in $\mathrm{pH}$ observed here is attributed to uptake of $\mathrm{CO}_{2}$ by the Teflon reaction vessels. Alkalinity determinations for these experiments are expected to underestimate the alkalinity of the rockwater system for this reason.

Changes in concentration occurred for aluminum, potassium, sodium, magnesium, and calcium as a result of reaction. Magnesium and calcium decrease due to the precipitations of $(\mathrm{Ca}, \mathrm{Mg}) \mathrm{CO}_{3}$ (Knauss et al., 1983). Aluminum increases to form a supersaturated condition followed by slow precipitation. The solubility of aluminum in this system appears to be controlled by gibbsite (Knauss et al., 1983). Potassium increases from 5 to 9 ppm, probably due to dissolution of alkali feldspar. There is no significant difference in potassium concentration as a function of temperature. Sodium increases are very small, and niay be due either to feldspar dissolution or to incomplete removal of the soluble material.

The results of the experiments at $120^{\circ} \mathrm{C}$ are consistent with those obtained for the same rockwater system at 90 and $150^{\circ} \mathrm{C}$ (Oversby, 1984).

\section{Acknowledgments}

The success of these experiments is the result of the contributions of many individuals. Thanks to the care and effort of Jan Brown we made effective use of laboratory time and space, and had no instances where experiments had to be rerun. Cation analyses were performed by $A$. Langhorst for samples run on the polychromator and by $T$. Duewer for samples run on the monochrometer system. Ion chromatography measurements were made by J. Lam, and alkalinity by R. Swanziger. Their careful measurements and attention to detail are greatly appreciated. Rock crushing, matrix execution, and pH measurements were done by Jan Brown. Without her efforts this work would not have been accomplished. T. Wolery provided the calculated solubility of cristobalite as a function of temperature. The manuscript was reviewed by L. Ballou, J: Delany, and K. Knauss; their time and effort are greatly appreciated. 


\section{REFERENCES}

Knauss, K. G. (1984), Petrologic and Geochemical Characterization of the Topopah Spring Member of the Paintbrush Tuff: Outcrop Samples used in Waste Package Experiments, Lawrence Livermore National Laboratory, Livermore,CA, UCRL-53558.

Knauss, K. G., V. M. Oversby, and T. J. Wolery (1983), Post Emplacement Environment of Waste Packages, Lawrence Livermore National Laboratory, Livermore, CA, UCRL-89475.

Oversby, V. M. (1983), Performance Testing of Waste Fonns in a Tuff Environment, Lawrence Livermore National Laboratory, Livermore, CA, UCRL-90045.

Oversby, V. M. (1984), Renction of the Topopah Spring Tuff with J-13 Well Water at $90^{\circ} \mathrm{C}$ and $150^{\circ} \mathrm{C}$, Lawrence Livermore National Laboratory, Livermore, CA, UCRL-53552.

Peck, E. S., A. L. Langhorst, and D. W. O'Brien (1979), Arralyses of Natural Waters tuith an Autonated Inductively Coupled Plasma Spectrometer System, Lawrence Livermore National Laboratory, Livermore, CA, UCRL-81043.

U.S. Nuclear Regulatory Commission (1983), 10 CFR Part 60, "Disposal of High-Level Radioactive Wastes in Geologic Repositories," Technical Criteria, Final Rule, Federal Register 48 (120).

Walther, J. V. and H. C. Helgeson (1977), Caiculation of the Thermodynamic Properties of Aqueous Silica and the Solubility of Quartz and its Polymorphs at High Temperatures and Pressures, Amer. Jour. Sci. 277, 1315-1351. 


\section{Appendix A}

Tables A1 through A5 duplicate the polychrometer ICP data from Tables 20, 21, 23, 24, and 27. Splits of these solutions were also analyzed on the new monochrometer ICP. Results of those analyses are given in Tables A1 through A5, labelled as Nx. Agreement of results from the two instruments is generally quite good for aluminum and sodium. Data for boron show somewhat more variability than expected for the new instrument. Silicon data show a systematic difference between the instruments, with the new instrument giving higher concentrations. The amount of the difference increases as the silicon concentration increases. Data for J-13 control blanks gave the same silicon values for both instruments (27 ppm, Table 1). The results for calcium are somewhat erratic and do not show the expected level of agreement. Further work with the new instrument will be necessary before it can be used for routine analyses.

Table A1. Comparison of results from polychromator ICP (Table 20) with monochromator ICP (new instrument). Aluminum concentration in ppm.

\begin{tabular}{|c|c|c|c|c|c|}
\hline \multirow{2}{*}{$\begin{array}{l}\text { Reaction time } \\
\text { (days) }\end{array}$} & \multicolumn{4}{|c|}{ Weight (grams) } & \multirow[b]{2}{*}{ Blank } \\
\hline & $\overline{0.40}$ & 0.80 & 1.60 & 3.20 & \\
\hline 1 & 1.29 & 1.90 & 1.85 & 1.52 & \\
\hline N1 & 1.45 & 2.14 & 1.94 & 1.59 & \\
\hline 3 & 1.62 & 2.05 & 1.96 & 1.43 & 0.011 \\
\hline N3 & 1.57 & 1.98 & 1.92 & 1.41 & $<0.03$ \\
\hline 6 & 1.91 & 2.13 & 1.84 & 1.34 & \\
\hline N6 & 1.91 & 2.15 & 1.78 & 1.29 & \\
\hline 12 & 1.74 & 1.96 & 1.69 & 1.24 & 0.019 \\
\hline N12 & 1.74 & 1.94 & 1.68 & 1.24 & $<0.08$ \\
\hline 24 & 1.78 & 2.10 & 1.69 & 1.17 & 0.016 \\
\hline N24 & 1.73 & 2.05 & 1.66 & 1.10 & $<0.08$ \\
\hline 36 & 1.77 & 2.12 & 1.73 & 1.17 & 0.015 \\
\hline N36 & 1.74 & 2.17 & 1.76 & 1.21 & $<0.08$ \\
\hline 48 & 1.68 & 1.95 & 1.68 & 1.18 & \\
\hline N48 & & 1.95 & 1.71 & & \\
\hline 60 & 1.58 & 1.78 & 1.38 & 1.09 & 0.015 \\
\hline N60 & & 1.46 & 1.46 & 1.13 & $<0.08$ \\
\hline 72 & 1.65 & 1.99 & 1.56 & 1.21 & \\
\hline N72 & & 2.09 & 1.58 & 1.27 & \\
\hline
\end{tabular}


Table A2. Comparison of results from polychromator ICP (Table 21) with monochromator XCP (new instrument?. Boron concentration in PPm.

\begin{tabular}{|c|c|c|c|c|c|}
\hline \multirow{2}{*}{$\begin{array}{l}\text { Reaction time } \\
\text { (days) }\end{array}$} & \multicolumn{4}{|c|}{ Weight (grams) } & \multirow[b]{2}{*}{ Dlank } \\
\hline & 0.40 & 0.80 & 3.60 & $3.20^{\circ}$ & \\
\hline 1 & 0.116 & 0.316 & 0.117 & 0.119 & \\
\hline N1 & 0.170 & 0.170 & 0.130 & 0.140 & \\
\hline 3 & 0.132 & 0.134 & 0.138 & 0.153 & 0.133 \\
\hline N3 & 0.160 & 0.170 & 0.160 & 0.170 & 0.160 \\
\hline 6 & 0.140 & 0.137 & 0.145 & 0.155 & \\
\hline N6 & 0.170 & 0.150 & 0.140 & 0.150 & \\
\hline 12 & 0.130 & 0.129 & 0.137 & 0.157 & 0.126 \\
\hline N12 & 0.100 & 0.100 & 0.130 & 0.120 & 0.110 \\
\hline 36 & 0.127 & 0.123 & 0.133 & 0.156 & 0.119 \\
\hline N36 & 0.110 & 0.120 & 0.130 & 0.140 & 0.110 \\
\hline 48 & 0.131 & 0.137 & 0.144 & 0.166 & \\
\hline N48 & 0.110 & 0.130 & 0.130 & 0.190 & \\
\hline 60 & 0.337 & 0.134 & 0.145 & 0.173 & 0.118 \\
\hline N60 & 0.180 & 0.170 & 0.170 & 0.200 & 0.140 \\
\hline 72 & 0.140 & 0.144 & 0.152 & 0.179 & \\
\hline N72 & J.130 & 0.130 & 0.130 & 0.150 & \\
\hline
\end{tabular}

Table A3. Comparison of results from polychromator ICP (Table 23) with monochromator ICP (new instrument). Sillicon concentration in Ppm.

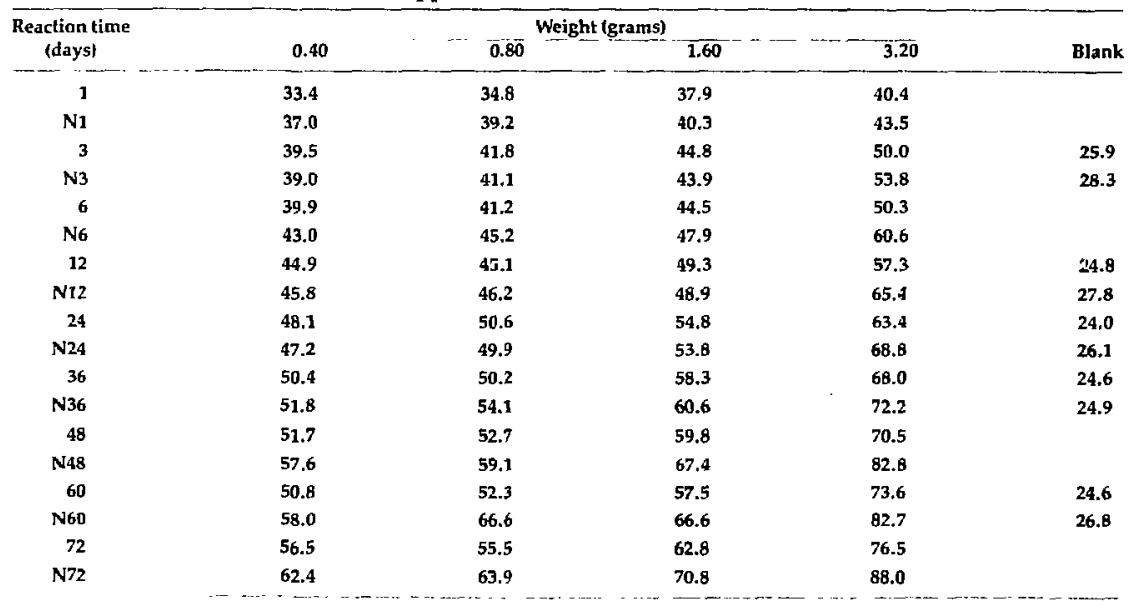


Table A4. Comparison of results from polychromator ICP (Table 24) with monochromator ICP (new instrument). Calcium concentration in ppm.

\begin{tabular}{|c|c|c|c|c|c|}
\hline \multirow{2}{*}{$\begin{array}{l}\text { Reaction time } \\
\text { (days) }\end{array}$} & \multicolumn{3}{|c|}{ Weight (grams) } & \multirow{2}{*}{$-\cdots-\square-3.20$} & \multirow[b]{2}{*}{ Blank } \\
\hline & 0.40 & 0.80 & 1.60 & & \\
\hline 1 & 6.71 & 7.09 & 8.84 & 9.41 & \\
\hline N1 & 7.00 & 7.70 & 9.30 & 11.00 & \\
\hline 3 & 7.63 & 7.95 & 9.26 & 10.30 & 5.21 \\
\hline N3 & 6.45 & 7.10 & 7.90 & B.52 & 4.10 \\
\hline 6 & 6.30 & 7.04 & 6.86 & 7.31 & \\
\hline N6 & 6.00 & 6.80 & 7.40 & 7.50 & \\
\hline 12 & 6.22 & 5.86 & 6.76 & 2.03 & 3.76 \\
\hline N12 & 5.7 & 5.31 & 6.10 & 5.97 & 2.80 \\
\hline 24 & 5.29 & 4.95 & 4.59 & 4.96 & 2.43 \\
\hline N24 & 3.70 & 3.54 & 2.94 & 1.54 & \\
\hline 36 & 4.17 & 3.75 & 3.97 & 4.19 & 2.05 \\
\hline N36 & 3.51 & 3.23 & 3.29 & 3.60 & 1.07 \\
\hline 48 & 4.62 & 4.95 & 3.94 & 4.11 & \\
\hline N48 & 3.57 & 3.98 & 3.00 & 3.39 & \\
\hline 60 & 4.88 & 4.47 & 4.48 & 4.34 & 2.26 \\
\hline N60 & 3.66 & 3.66 & 3.79 & 3.32 & 1.17 \\
\hline 72 & 3.44 & 3.63 & 3.74 & 3.59 & \\
\hline N72 & 2.35 & 2.78 & 2.82 & 2.68 & \\
\hline
\end{tabular}

Table A5. Comparison of results from polychromator ICP (Table 27) with monochromator ICP (new instrument). Sodium concentration in ppm.

\begin{tabular}{|c|c|c|c|c|c|}
\hline \multirow{2}{*}{$\begin{array}{l}\text { Reaction time } \\
\text { (days) }\end{array}$} & \multicolumn{5}{|c|}{ Weight (grams' } \\
\hline & -0.40 & 0.80 & 1.60 & 3.20 & Blank \\
\hline 1 & 41.0 & 40.3 & 43.4 & 42.4 & \\
\hline N1 & 45.0 & $\mathbf{4 4 . 0}$ & 46.0 & 48.0 & \\
\hline 3 & 45.9 & 46.2 & 51.3 & 52.3 & 46.2 \\
\hline N3 & 44.4 & 44.1 & 41.2 & 46.6 & 44.8 \\
\hline 6 & 43.3 & 44.7 & 44.5 & 46.2 & \\
\hline N6 & 46.0 & 47.0 & 47.0 & 49.0 & \\
\hline 12 & 43.0 & 42.2 & 45.2 & 47.1 & 40.6 \\
\hline $\mathrm{N} 12$ & 43.2 & 43.0 & 42.4 & 26.0 & 46.8 \\
\hline 24 & 46.5 & 46.8 & 45.3 & 45.4 & 40.7 \\
\hline $\mathrm{N} 24$ & 43.4 & 41. 1 & 39.5 & $\mathbf{4 4 . 8}$ & 39.8 \\
\hline 36 & 44.7 & 43.1 & 44.0 & 45.1 & 39.5 \\
\hline N36 & 46.2 & 47.4 & 44.9 & 48.3 & 48.3 \\
\hline 48 & 45.4 & 46.1 & 45.6 & 47.3 & \\
\hline N48 & 49.5 & 46.5 & 46.6 & 46.9 & \\
\hline 60 & 42.7 & 44.1 & 44.6 & 51.1 & 40.9 \\
\hline N60 & 47.8 & 46.5 & 44.9 & 52.2 & 41.2 \\
\hline 72 & 46.5 & 44.7 & 47.0 & 50.4 & \\
\hline N72 & 51.2 & 46.1 & 48.2 & 47.6 & \\
\hline
\end{tabular}

